\title{
Sub-Antarctic marine aerosol: dominant contributions from biogenic sources
}

\author{
J. Schmale ${ }^{1,2, *}$, J. Schneider ${ }^{1}$, E. Nemitz ${ }^{2}$, Y. S. Tang ${ }^{2}$, U. Dragosits ${ }^{2}$, T. D. Blackall ${ }^{3}$, P. N. Trathan ${ }^{4}$, G. J. Phillips ${ }^{1}$, \\ M. Sutton ${ }^{2}$, and C. F. Braban ${ }^{2}$ \\ ${ }^{1}$ Max Planck Institute for Chemistry, Mainz, Germany \\ ${ }^{2}$ NERC Centre for Ecology \& Hydrology, Edinburgh, UK \\ ${ }^{3}$ Kings College London, London, UK \\ ${ }^{4}$ British Antarctic Survey, Cambridge, UK \\ * now at: Institute for Advanced Sustainability Studies e.V., Potsdam, Germany
}

Correspondence to: J. Schmale (julia.schmale@gmail.com)

Received: 5 March 2013 - Published in Atmos. Chem. Phys. Discuss.: 27 March 2013

Revised: 5 July 2013 - Accepted: 22 July 2013 - Published: 3 September 2013

\begin{abstract}
Biogenic influences on the composition and characteristics of aerosol were investigated on Bird Island $\left(54^{\circ} 00^{\prime} \mathrm{S}, 38^{\circ} 03^{\prime} \mathrm{W}\right)$ in the South Atlantic during November and December 2010. This remote marine environment is characterised by large seabird and seal colonies. The chemical composition of the submicron particles, measured by an aerosol mass spectrometer (AMS), was $21 \%$ non-sea-salt sulfate, $2 \%$ nitrate, $8 \%$ ammonium, $22 \%$ organics and $47 \%$ sea salt including sea salt sulfate. A new method to isolate the sea spray signature from the high-resolution AMS data was applied. Generally, the aerosol was found to be less acidic than in other marine environments due to the high availability of ammonia, from local fauna emissions. By positive matrix factorisation five different organic aerosol (OA) profiles could be isolated: an amino acid/amine factor (AA-OA, $18 \%$ of OA mass), a methanesulfonic acid OA factor (MSA-OA, $25 \%$ ), a marine oxygenated OA factor (M-OOA, $41 \%$ ), a sea spray OA fraction (SS-OA, $7 \%$ ) and locally produced hydrocarbon-like OA (HOA, 9\%). The AA-OA was dominant during the first two weeks of November and found to be related with the hatching of penguins in a nearby colony. This factor, rich in nitrogen $(\mathrm{N}: \mathrm{C}$ ratio $=0.13)$, has implications for the biogeochemical cycling of nitrogen in the area as particulate matter is often transported over longer distances than gaseous N-rich compounds. The MSA-OA was mainly transported from more southerly latitudes where phytoplankton bloomed. The bloom was identified as one of three sources for particulate sulfate on Bird Island, next to sea salt sulfate
\end{abstract}

and sulfate transported from South America. M-OOA was the dominant organic factor and found to be similar to marine OA observed at Mace Head, Ireland. An additional OA factor highly correlated with sea spray aerosol was identified (SS-OA). However, based on the available data the type of mixture, internal or external, could not be determined. Potassium was not associated with sea salt particles during $19 \%$ of the time, indicating the presence of biogenic particles in addition to the MSA-OA and AA-OA factors.

\section{Introduction}

The marine environment represents one of the largest natural aerosol sources (Rinaldi et al., 2010), driven by the emission of $133 \mathrm{Tg} \mathrm{yr}^{-1}$ submicron particulate matter from sea spray, including primary and secondary organic matter (together 13\%) and sea salt (Vignati et al., 2010; Gantt et al., 2011). Marine aerosol systems are important as they exert a significant influence on the Earth's radiative balance through provision of a large number of cloud condensation nuclei (e.g. Meskhidze et al., 2011). At the same time, marine particulate matter plays a substantial role in biogeochemical cycling of chemical elements and nutrients (O'Dowd and de Leeuw, 2007). Numerous recent studies have been conducted to investigate the role of marine organic aerosol for these important functions. They have focused on the characterisation and quantification of primary and secondary marine organic 
aerosol (Cavalli et al., 2004; Facchini et al., 2008b; Hawkins and Russell, 2010; Ceburnis et al., 2011; Decesari et al., 2011; Gantt et al., 2011; Lapina et al., 2011; Ovadnevaite et al., 2011; Dall'Osto et al., 2012; Gantt and Meskhidze, 2013) and the production of primary organic aerosol from sea spray (Gantt et al., 2011; O'Dowd et al., 2008). Whilst the emission of primary organic aerosol (POA) is associated with wave breaking and the bubble bursting process and hence related to wind speed (e.g. Blanchard and Woodcock, 1957; Russell et al., 2010; Gantt et al., 2011), the production of secondary marine organic aerosol is associated with biologically driven emissions of volatile organic compounds such as dimethyl sulfide from phytoplankton (e.g. Bates et al., 1992). POA contains organic matter originating from the sea-surface micro layer consisting of immiscible substances such as colloids and aggregates from phytoplankton (Facchini et al., 2008b). However, despite such research efforts, many aspects of marine aerosol systems are not yet fully understood, particularly with respect to chemical composition, sources, secondary particle formation processes and chemically resolved size distributions among other topics. A detailed understanding of these aspects is essential to quantify the role of marine aerosol in the functioning of the Earth system more fully.

Further studies on the biogenic organic fraction of marine aerosol are essential, as they may help distinguish anthropogenic from natural climate forcing in the marine atmosphere. Biological components of marine organic aerosol (MOA) consist of whole viruses, bacteria and other microbiological organisms, biological debris and by-products including proteins, amino acids and amines (Aller et al., 2005; Kuznetsova et al., 2005; O'Dowd et al., 2004; Facchini et al., 2008a; Russell et al., 2010; Scalabrin et al., 2012). The physical and chemical properties of these organic components will affect the radiative properties, cloud condensation and icenucleating abilities of the particulate matter (PM) they are part of. Modelling studies such as Burrows et al. (2013) have looked at the role of biogenic ice nuclei in the marine environment and found that they are of particular importance in the Southern Ocean, where the authors recommend conducting field studies due to the lack of data. To date, few studies have been conducted on MOA in the remote middle- to highlatitude Southern Hemisphere (Bates et al., 1998; Quinn et al., 1998; Pósfai et al., 2003; Zorn et al., 2008; Sciare et al., 2009; Claeys et al., 2010; Lapina et al., 2011), and even fewer investigations of MOA source apportionment (Chang et al., 2011; Decesari et al., 2011) are available.

The perturbation of the composition of the remote southern hemispheric MOA by large animal colonies (e.g. macaroni penguin Eudyptes chrysolophus, gentoo penguin Pygoscelis papua and Antarctic fur seal Arctocephalus gazella) has been reported in a number of studies. For example, Legrand et al. (1998) and Zhu et al. (2011) observed high ammonia emissions from penguin and seal excreta and colony soils during the summer months associated with less-acidic, sulfate-rich marine aerosol. It was concluded that this effect was due to the ammonia partitioning from the gas phase into the particulate phase. Blackall et al. (2007) estimated that seabird emissions add about $20 \%$ to the oceanic ammonia emissions south of $45^{\circ} \mathrm{S}$, using a global seabird database coupled to an emissions model. Calculations based on the same model and database by Riddick et al. (2012) found that penguins are responsible for about $80 \%$ of the global seabird $\mathrm{NH}_{3}$ emissions. Because such emissions are dominated by "hot spots", i.e. densely populated colonies, they drive the local nitrogen cycle and will also affect the regional biogeochemistry by both gas emissions and aerosol chemistry. In addition to ammonia, decomposition of ornithogenic soils is thought to make a significant contribution to the organic matter contained in particulates through oxalate enrichments (Legrand et al., 2012). Particles have slower deposition rates than reactive gas-phase species, such as ammonia or certain volatile organic species (Nemitz et al., 2009). Thus, gasto-particle conversion enables transport of chemical species over longer distances and hence broadening the footprint of these large sources and potentially increasing the range of impacts on ecosystems.

In this paper we report measurements of the chemical and microphysical characteristics of remote marine aerosol on Bird Island, to the west of South Georgia, a remote oceanic archipelago south of the Antarctic Polar Front in the South Atlantic Ocean, and assess the influence of emissions from local fauna compared with regional sources. Measurements were conducted during austral spring, the peak time for biological activity. The island is densely populated by penguins and fur seals. It is estimated that there is about one seal and penguin for every $1.5 \mathrm{~m}^{2}$. This paper details the results from an aerosol mass spectrometer operated at the Bird Island research station of the British Antarctic Survey for eight weeks, with other ancillary measurements made at several locations on the island. This represents the first stationary deployment of an aerosol mass spectrometer in the sub-Antarctic. The sources of organic aerosol were apportioned using positive matrix factorisation, and special emphasis was placed on the investigation of biogenic contributions to particulate matter and the sources of organic and inorganic nitrogen.

\section{Experimental and methods}

\subsection{Measurement site}

Measurements were conducted at the research station on remote sub-Antarctic Bird Island $\left(54^{\circ} 00^{\prime} \mathrm{S}, 38^{\circ} 03^{\prime} \mathrm{W}\right)$ over an 8 -week period in November and December 2010. The island is approximately $4 \mathrm{~km}$ long and $800 \mathrm{~m}$ wide, with a hilly topography and a maximum elevation of $350 \mathrm{~m}$ (see Fig. 1 and details on the website www.antarctica.ac.uk/living_and_ working/research_stations/bird_island/). The island is an important breeding location for seabirds and seals in the austral 


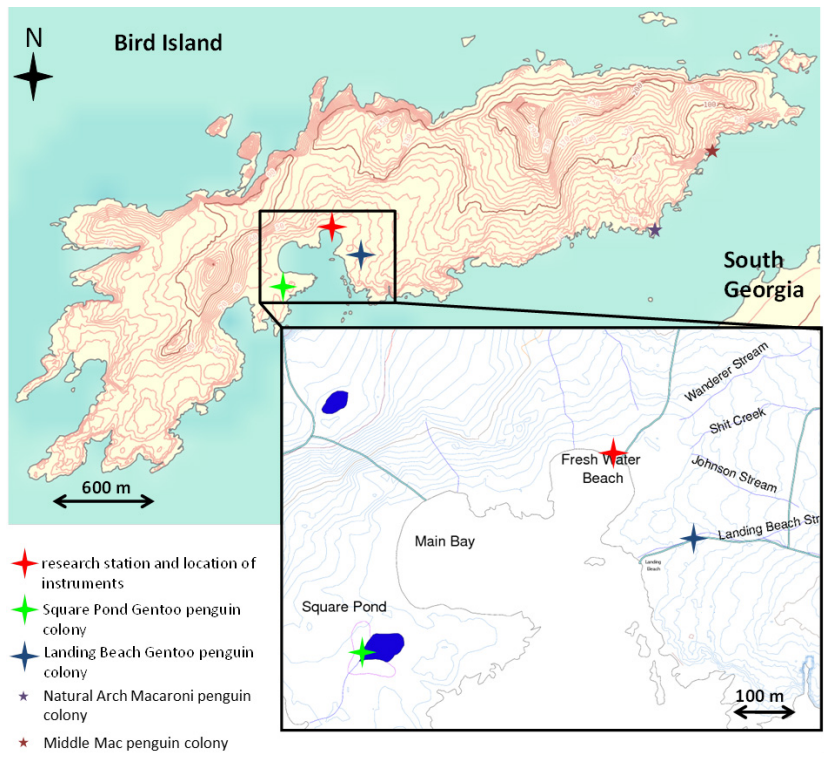

Fig. 1. Map of Bird Island and zoom on the surroundings of the research station (large red star), also showing the location of two nearby gentoo penguin colonies (large green star and blue star). Small stars indicate other penguin colonies on Bird Island which influenced the organic aerosol composition measured at the research station. The thick dark-red contours on the main map and insert map indicate $100 \mathrm{~m}$ altitude steps (GIS map source: British Antarctic Survey).

spring. The largest assemblages of fauna on Bird Island are the colonies of macaroni penguin Eudyptes chrysolophus, gentoo penguin Pygoscelis papua and Antarctic fur seal Arctocephalus gazella. The immediate surroundings of the field station were inhabited by more than 3500 fur seals and 1000 penguins in spring and summer 2010/2011. The island as a whole is home to about 50000 breeding pairs of penguins, 14000 pairs of albatrosses, 700000 nocturnal petrels and 65000 breeding fur seals. Further large animal colonies are found on the neighbouring islands to the west, Willis Islands, and to the east, South Georgia. The main research activities focus on seabird (penguins, albatross and petrels among others) and seal population dynamics, feeding ecology and reproduction statistics. The predominant mesoscale wind direction is from the west. However the local topography and the quasi-permanent winds lead to atmospheric turbulence and hence to the mixing of aerosol produced locally by seabirds and seals, with air masses arriving with the predominant westerlies. The Bird Island research station is located about $50 \mathrm{~m}$ from the shore in a sheltered bay on the south side of the island (see red star in Fig. 1).

\subsection{Aerosol mass spectrometer}

The chemical composition of submicron aerosol was determined with a high-resolution time-of-flight (HR-ToF-) aerosol mass spectrometer (AMS). The functioning and field deployment of the AMS has been extensively described in the literature (DeCarlo et al., 2006; Canagaratna et al., 2007). On Bird Island the AMS was operated alternating between the $\mathrm{W}$ - and V-modes. In W-mode, the ion path length in the mass spectrometer is $2.9 \mathrm{~m}$, leading to higher mass-to-charge ratio resolution than the $\mathrm{V}$-mode where the ions follow a path of $1.3 \mathrm{~m}$. However, in V-mode detection limits are lower (DeCarlo et al., 2006). Both W-mode and V-mode were averaged over $150 \mathrm{~s}$ each. In $\mathrm{W}$-mode only mass spectra were recorded and the sampling switched every $5 \mathrm{~s}$ between the open and closed positions of the chopper. In V-mode, $60 \%$ of the time mass spectra were recorded at $15 \mathrm{~s}$ in both open and closed chopper positions, while during $40 \%$ of the time the particle size distribution was measured. Only the V-mode spectra were used to derive the aerosol mass concentrations reported in this work. W-mode spectra were only used to identify individual ion fragments when the V-mode resolution was not sufficient. The vaporiser was set to $600^{\circ} \mathrm{C}$. Mass concentrations for particulate sulfate (abbreviated as $\left(\mathrm{SO}_{4}^{2-}\right)$ ), ammonium $\left(\mathrm{NH}_{4}^{+}\right)$, organic matter $(\mathrm{Org})$, nitrate $\left(\mathrm{NO}_{3}^{-}\right)$, chloride $\left(\mathrm{Cl}^{-}\right)$and potassium $\left(\mathrm{K}^{+}\right)$are reported. In addition, we report an estimation of sea salt submicron aerosol (for details see Sect. 2.2.2).

\subsubsection{AMS data analysis, calibration, collection efficiency, limit of detection and error estimation}

All AMS data were analysed using standard analysis software (SQUIRREL $1.51 \mathrm{H}$ and PIKA 1.10H; Sueper, 2012) within Igor Pro 6.2 (Wavemetrics, Lake Oswego, OR, USA). The reported mass concentrations of $\mathrm{SO}_{4}^{2-}$, Org, $\mathrm{NO}_{3}^{-}, \mathrm{NH}_{4}^{+}$, $\mathrm{Cl}^{-}$and $\mathrm{K}^{+}$were derived from the high-resolution data PIKA analysis performed up to $m / z 128$.

The ionisation efficiency (IE), with respect to $\mathrm{NO}_{3}^{-}$, in $\mathrm{V}$ mode was calibrated twice every week with $400 \mathrm{~nm}$ mobility diameter $\left(d_{\mathrm{mob}}\right)$ ammonium nitrate particles at a pulsing period of $25 \mu \mathrm{s}$ for the extraction of ions into the mass spectrometer. IE values were averaged for every two weeks and applied to the data corresponding to these measurement periods. The W-mode IE was estimated to be the same fraction of the V-mode IE as is the W-mode MS air beam intensity of the V-mode MS air beam. After each IE calibration a highefficiency particulate air (HEPA) particle filter was installed in front of the instrument to sample ambient air between $30 \mathrm{~min}$ and one hour for the determination of the detection limits. The limit of detection was calculated as three times the standard deviation from the mean species concentration during all filter measurements (see Table 1). The relative IE (RIE) for ammonium was found to agree with the default value of 4 , based on the mass spectrum ammonium nitrate data from IE calibrations. The RIE for $\mathrm{SO}_{4}^{2-}$ was determined by comparing the theoretical to measured mass concentration of sulfate in a solution of ammonium nitrate and ammonium sulfate. The resulting $\mathrm{RIE}_{\mathrm{SO}_{4}^{2-}}$ was 1.14 (default value 1.2). Size calibrations were conducted twice, in the first and 
Table 1. Limit of detection (LOD) and statistical ion counting error $\left(E_{\mathrm{IS}}\right)$.

\begin{tabular}{lrr}
\hline Species & LOD $\left(\mu \mathrm{g} \mathrm{m}^{-3}\right)$ & $E_{\mathrm{IS}}\left(\mu \mathrm{g} \mathrm{m}^{-3}\right)$ \\
\hline Sulfate & 0.024 & $0.006 \pm 0.001$ \\
Organics & 0.06 & $0.012 \pm 0.00$ \\
Nitrate & 0.006 & $0.002 \pm 0.001$ \\
Ammonium & 0.02 & $0.02 \pm 0.002$ \\
Chloride & 0.012 & $0.012 \pm 0.012$ \\
Potassium & 0.002 & $0.009 \pm 0.002$ \\
\hline
\end{tabular}

last week of the campaign, using polystyrene latex spheres (PSL).

Due to the island's unusual organic aerosol composition, for the unit mass resolution mass spectral analysis, the fragmentation table had to be edited at $\mathrm{m} / \mathrm{z} 30$ where the fragments $\mathrm{CH}_{2} \mathrm{O}^{+}$and $\mathrm{CH}_{4} \mathrm{~N}^{+}$occasionally dominated over $\mathrm{NO}^{+}$. Normally, frag_nitrate[30] is calculated as $m / z 30 \mathrm{mi}-$ nus the contributions from air and organics at this massto-charge ratio, where the latter is referenced to the organic signal at $m / z 29$ (Allan et al., 2004b). However, since the organic contribution as assumed by the standard fragmentation table did not apply, the nitrate contribution at $\mathrm{m} / \mathrm{z} 30$ was set to be fixed to its contribution at $\mathrm{m} / \mathrm{z} 46$ (3.92*frag_nitrate[46]), based on the data from all IE calibrations. Thus, the organic mass at $m / z 30$ was calculated as m/z 30 minus frag_air[30] and minus frag_nitrate[30].

The determination of the Bird Island ambient aerosol collection efficiency (CE), including losses due to incomplete particle transmission in the instrument's inlet system, malfocusing of non-spherical particles and bounce-off from the vaporiser (Huffman et al., 2005), was difficult for several reasons. In theory, knowing the particle density, size distributions derived from AMS measurements can be compared to scanning mobility particle sizer (SMPS) size distributions to yield the collection efficiency (CE). The AMS provides the vacuum aerodynamic diameter $\left(d_{\mathrm{va}}\right)$ of a particle, while the SMPS measures the mobility diameter $\left(d_{\mathrm{mob}}\right)$. Diameters $d_{\mathrm{va}}$ and $d_{\text {mob }}$ are related by the following equation after DeCarlo et al. (2004):

$d_{\mathrm{va}}=d_{\mathrm{mob}} \cdot S \cdot \frac{\rho_{\mathrm{p}}}{\rho_{0}}$,

with $S$ being the Jayne shape factor, $\rho_{\mathrm{p}}$ the particle density and $\rho_{0}$ the unit density. However, due to the significant influence of sea spray in the submicron particulates, the SMPS accounts for a larger number of particles than the AMS. Even though the AMS sees a fraction of the submicron sea salt, it cannot be quantified (see Sect. 2.2.2). In addition, mass concentrations were rather low with $0.22 \mu \mathrm{g} \mathrm{m}^{-3}(\mathrm{CE}=1)$ on average, so that AMS-derived size distributions were very noisy. In addition, the flow split was not strictly isokinetic. All factors would introduce too-large errors to calculate a reasonable CE. See the Supplement for more information on the correlation between SMPS and AMS data. Alternatively, CE can be determined based on its dependency on the $\mathrm{NO}_{3}^{-}$fraction (Crosier et al., 2007; however Bird Island $\mathrm{NO}_{3}^{-}$concentrations were invariably low, with approximately $0.003 \mu \mathrm{g} \mathrm{m}^{-3}(\mathrm{CE}=1)$ on average, and were thus not suitable for a method developed for urban aerosol. Based on previous measurements in marine environments, it is known that the CE of the acidic marine aerosol is near one due to the high contribution of sulfuric acid and the prevailing liquid phase of particles (Quinn et al., 2006; Matthew et al., 2008; Zorn et al., 2008). However, Bird Island is characterised by many large seabird colonies and Antarctic fur seal rookeries that emit quantities of ammonia leading to ambient concentrations of up to $350 \mathrm{\mu g} \mathrm{m}^{-3}$ (unpublished data), leading mostly to neutralised aerosol (see Sect. 3.2) despite the strong marine influence. Consequently, effloresced ammonium bisulfate and ammonium sulfate salts are formed which tend to bounce off the heating element in the AMS more frequently. In the absence of another instrument to which AMS results could have been compared, the collection efficiency was set to $\mathrm{CE}=0.5$, based on experiences from several earlier field campaigns with this particular and other AMS instruments (e.g. Allan et al., 2004a; Drewnick et al., 2005; Hings et al., 2007). In addition to the uncertainties in aerosol mass concentration quantification due to the $\mathrm{CE}$, there is also a statistical ion counting error (see Table 1).

\subsubsection{AMS sea salt detection and its influence on particulate organics and sulfate quantification}

Formerly, sea salt was considered to be undetectable by the AMS due to the refractory nature of sea salt at a vaporisation temperature of around $600^{\circ} \mathrm{C}$ (Bahreini et al., 2003; Jimenez et al., 2003). However, a recent study attempted to quantify the sea salt mass concentrations detected by the AMS (Ovadnevaite et al., 2012). Following the Bird Island field campaign, additional laboratory measurements were undertaken with a different AMS (compact time-of-flight aerosol mass spectrometer as described by Schmale et al., 2010) to characterise the extent to which the AMS is capable of sea salt quantification and identify potential cross-sensitivities to other AMS standard chemical species. These laboratory measurements are described in detail in the supplementary material. Comparison of the results with other available literature suggests that AMS sea salt quantification needs more thorough investigation and might be highly dependent on specific instruments. Zorn (2009) found a scaling factor for chloride to sea salt between 150 and 220 in the South Atlantic, based on a comparison between measurements of an AMS and a particle-into-liquid sampler (PILS; Zorn et al., 2008), as opposed to the method here applied based only on $\mathrm{AMS} \mathrm{NO}_{3}^{-}$ quantification which resulted in a scaling factor ranging between of $3.15 \pm 0.20$ and $3.97 \pm 0.14$ across all experiments. Ovadnevaite et al. (2012) determined a scaling factor between the $\mathrm{NaCl}^{+}$reported by the AMS and the actual sea salt 
contained in $\mathrm{PM}_{1}$ (particulate matter with a diameter equal to or smaller $1 \mu \mathrm{m}$ ) of 51 , while our experiments yielded a factor 13 .

To be consistent with available data from the existing literature, mass-concentration-related data for sea salt reported in this study have been determined on the basis of the intensity of $m / z 57.95\left(\mathrm{Na}^{35} \mathrm{Cl}^{+}\right)$and scaled up using the factor of 51, as suggested by Ovadnevaite et al. (2012).

In addition, to the question whether submicron sea salt can be quantified by the AMS, the potential influence of the presence of ambient sea salt particles on the quantification of other chemical species was investigated, assessing the validity of the standard fragmentation table. One observed sea salt ion fragment is $\mathrm{Na}_{2} \mathrm{Cl}^{+}$at $m / z 81$, which is typically interpreted as the $\mathrm{HSO}_{3}^{+}$fragment of particulate sulfate in the unit mass resolution spectrum. To correct for this interference, the concentration of $\mathrm{Na}_{2} \mathrm{Cl}^{+}$at $m / z 81$ in the HR spectrum was correlated to $m / z 23$ where only the $\mathrm{Na}^{+}$fragment is observed. The linear regression yielded a correlation coefficient $R^{2}$ of 0.99 and a slope of 0.036 across all data. The fragmentation table for the unit mass resolution (UMR) data was edited as follows:

$$
\begin{aligned}
& \text { frag_SO4[81] }=81-\text { frag_organic[81] } \\
& -0.036 \times \text { frag_Na[23]. }
\end{aligned}
$$

The correction makes a difference on the order of $1 \%$ for the total particulate $\mathrm{SO}_{4}^{2-}$.

The presence of sea salt particles is responsible for artefacts in the UMR organics spectrum. For example, tungsten emitted from the filament in the ion source reacts with $\mathrm{Cl}^{-}$. $\mathrm{WCl}, \mathrm{WOCl}$ and $\mathrm{WOCl}_{2}$ isotopes between $m / z 214$ and 276 and sea salt fragments as listed in Table 2 contribute to the standard particulate organics quantification. To avoid overestimation of organics due to this effect, only mass-to-charge ratios up to 232 were considered, as non-organic peaks completely dominated the mass above this threshold. Laboratory experiments indicate that the quantification of particulate organics with mass-to-charge ratios smaller than 232 might also be influenced by the amount of sea salt present. However, no clear pattern could be isolated. Deriving the organic mass concentration from the PIKA HR analysis however circumvents this potential UMR problem.

\subsubsection{Positive matrix factorisation}

Positive matrix factorisation (PMF; Paatero and Tapper, 1994; Lanz et al., 2007) was applied to the V-mode UMR organic spectra obtained by the AMS, to investigate the various source contributions to the submicron aerosol organic matter (PMF v2.04 based on Ulbrich et al., 2009). Details of the mathematical model behind the algorithm, its application, the result evaluation and the interpretation have been described elsewhere (e.g. Lanz et al., 2007; Ulbrich et al., 2009; Ng et al., 2010; Zhang et al., 2011). Briefly, the underlying assumption of this bilinear problem is, with respect

\begin{tabular}{|c|c|c|c|}
\hline Ion fragment & Exact mass & Ion fragment & Exact mass \\
\hline $\mathrm{Na}$ & 22.99 & $\mathrm{Na}_{2}^{35} \mathrm{Cl}$ & 80.95 \\
\hline $\mathrm{Mg}$ & 23.98 & $\mathrm{Na}_{2}^{37} \mathrm{Cl}$ & 82.94 \\
\hline${ }^{25} \mathrm{Mg}$ & 24.98 & ${ }^{54} \mathrm{Fe}^{25} \mathrm{Cl}$ & 88.91 \\
\hline${ }^{26} \mathrm{Mg}$ & 25.98 & $\mathrm{Zr}$ & 89.90 \\
\hline $\mathrm{NaMg}$ & 46.97 & $\mathrm{Fe}^{35} \mathrm{Cl}$ & 90.90 \\
\hline $\mathrm{Mn}$ & 54.94 & $\mathrm{Fe}^{37} \mathrm{Cl}$ & 92.90 \\
\hline OK & 54.96 & ${ }^{94} \mathrm{Zr}$ & 93.91 \\
\hline $\mathrm{Fe}$ & 55.93 & $\mathrm{Mg}^{35} \mathrm{Cl}_{2}$ & 93.92 \\
\hline $\mathrm{Ni}$ & 57.94 & $\mathrm{Mg}^{37} \mathrm{Cl}^{35} \mathrm{Cl}$ & 95.92 \\
\hline $\mathrm{Na}^{35} \mathrm{Cl}$ & 57.96 & ${ }^{25} \mathrm{Mg}^{37} \mathrm{Cl}^{35} \mathrm{Cl}$ & 96.92 \\
\hline $\mathrm{Mg}^{35} \mathrm{Cl}$ & 58.95 & $\mathrm{Mg}^{37} \mathrm{Cl}_{2}$ & 97.92 \\
\hline $\mathrm{Na}^{37} \mathrm{Cl}$ & 59.96 & ${ }^{25} \mathrm{Mg}^{37} \mathrm{Cl}_{2}$ & 98.92 \\
\hline $\mathrm{Mg}^{37} \mathrm{Cl}$ & 60.95 & $\mathrm{Fe}^{35} \mathrm{Cl}_{2}$ & 125.87 \\
\hline & 69.94 & $\mathrm{Fe}^{37} \mathrm{Cl}^{35} \mathrm{Cl}$ & 127.87 \\
\hline${ }^{37} \mathrm{Cl}^{35} \mathrm{Cl}$ & 71.93 & & \\
\hline
\end{tabular}

Table 2. Ion fragments considered within the sea salt family.

to AMS data, that the dataset can be divided into a number of unvaried components, i.e. chemical mass spectra, which contribute with varying concentrations over time to the total organic matter measured. The problem is reduced to an $m \times n$ matrix $\mathbf{X}$ as shown in Eq. (3) (with $m$ being the number of rows, i.e. number of time steps, and $n$ the number of mass-to-charge ratios):

$\mathbf{X}=\mathbf{G F}+\mathbf{E}$.

F is a $p \times n$ matrix with $p$ being the number of factor profiles, i.e. constant AMS mass spectra, $\mathbf{G}$ is an $m \times p$ matrix with the respective mass spectra contributions, and $\mathbf{E}$ is the $m \times n$ matrix of residuals. $\mathbf{G}$ and $\mathbf{G}$ are fitted to minimise the sum of the weighted squared residuals $Q$.

$Q=\sum_{i=1}^{m} \sum_{j=1}^{n}\left(e_{i j} / \sigma_{i j}\right)^{2}$

with $e_{i j}$ being the residual not fitted by the model for $m / z j$ at time step $i$, and $\sigma_{i j}$ being an element of $\mathbf{E}$.

The input matrices were prepared following the recommendations by Ulbrich et al. (2009) and Zhang et al. (2011), and comprised a range of mass-to-charge ratios between 12 and 232 at a time resolution of 5 minutes. PMF was run to explore solutions between 1 and 8 factors, for fpeaks (rotations) between -1 and 1 (in steps of 0.2 ), and seeds (starting guesses) between 0 and 50 (in steps of 2). It is recommended to run PMF for a range of fpeaks so that the range of values for $Q / Q_{\exp }$ is at least $3 \%$ above the minimum $Q / Q_{\exp }$ (Zhang et al., 2011). As this was not the case for running fpeaks between -1 and 1 , we explored solutions of fpeaks between -5 and 5 (in steps of 1); see the Supplement for further details. Fpeaks is a rotational forcing parameter for exploring the rotational freedom of the chosen solution. Fpeaks 
$=0$ results in the most central solution. Seeds are random initial values where the algorithm's iterations are started.

The detailed criteria for the final selection of factor profiles are discussed in the Results section and in the supplementary material, following the same steps as indicated in Zhang et al. (2011). Zhang et al. (2011) suggest downweighting the signals at $\mathrm{m} / \mathrm{z}$ with a low signal to noise ratio and $\mathrm{m} / \mathrm{z} 44$ and associated $\mathrm{m} / \mathrm{z}$ that contain repetitive information (see step $2 \mathrm{~d}$ and e, Table 1 in Zhang et al., 2011). For this study, $\mathrm{m} / \mathrm{z} 29$ was also downweighted, as a potential leak in the instrument's vacuum chamber was likely to be the major source of variation in the signal at that $m / z$. We refer the reader to the Supplement, where the influence of $m / z 29$ is elaborated upon.

The statistical uncertainty of each factor's mass spectrum and time series was determined through bootstrapping (U1brich et al., 2009). For that purpose PMF was run on the full dataset once, and a series of 100 variations. In each variation a subset of the original rows (mass spectra) was randomly replaced by other rows from the original input. The result yields the $1 \sigma$-standard deviation from the mean mass spectra and time series of the bootstrapped solutions. Results are shown in Table S2 in the Supplement. Generally, the statistical uncertainty ranged from 3 to $16 \%$ for the mass spectra and 3 to $9 \%$ for the time series. Compared to other studies with higher mass loading these relative uncertainties are higher (e.g. Ulbrich et al., 2009).

In addition, the uncertainties of the chosen PMF solutions (mass spectra and time series) were calculated based on the variations of the results when fpeaks and seeds were varied. Freutel et al. (2013) elaborate upon how the estimated uncertainties for each data point, i.e. each $m / z$ and time step, were calculated. For each solution the average and the standard deviation were determined. For the relative uncertainty of the mass spectra, the sum of the absolute standard deviations for each $m / z$ was divided by the sum of the signal intensities of the average mass spectrum. For the relative uncertainties of the time series for each factor profile, the time series of the absolute standard deviation was divided by the average time series. In general, varying seeds did not result in large uncertainties (from 1 to $5 \%$ for mass spectra and below $1 \%$ for time series), while varying fpeaks resulted in larger uncertainties (from 16 to $76 \%$ for mass spectra and $15-130 \%$ for time series). Full results are shown and discussed in Table S2 in the Supplement.

\subsection{Sub- and super-micron particle size distribution measurements}

The size distribution of submicron aerosol particles was measured by an SMPS system (model 3936, TSI Inc., St. Paul, MN, USA) composed of a long DMA model 3081 and an ultrafine condensation particle counter (model 3776). The SMPS scanned for particles in the size range between 14 and $737 \mathrm{~nm}$ mobility diameter in 112 discrete steps and in $300 \mathrm{~s}$ intervals. Due to diffusion losses in the long inlet line, particles below approximately $25 \mathrm{~nm}$ were not detected, as can be clearly seen in the individual size distributions for each scan. As described in Sect. 2.4, the particle size distributions and the resultant calculated total number concentrations were corrected for the estimated transmission losses of the inlet.

Super-micron particles in the range between 0.5 and $20 \mu \mathrm{m}$ aerodynamic diameter $\left(d_{\mathrm{a}}\right)$ were detected in 53 discrete size bins by a TSI aerodynamic particle sizer (APS) model 3321, which determines the particle size via the time of flight between two $633 \mathrm{~nm}$ He-Ne lasers. The particle counting efficiency decreases below $100 \%$ at $d_{\mathrm{a}}<0.7 \mu \mathrm{m}$, and concentrations below this threshold should be interpreted as lower limit (Peters and Leith, 2003). The inlet flow was $5 \mathrm{~L} \mathrm{~min}^{-1}$ and split into $1 \mathrm{~L} \mathrm{~min}^{-1}$ sample and $4 \mathrm{~L} \mathrm{~min}^{-1}$ sheath flow. To minimise losses of super-micron particles in the inlet line, size distribution measurements were recorded at a time resolution of $300 \mathrm{~s}$ on the communications tower of the research station, approximately $5 \mathrm{~m}$ to the south of the building at a height of $10 \mathrm{~m}$ above ground. The approximate air-line distance to the AMS/SMPS inlet was $15 \mathrm{~m}$. The aerosol was sampled via a $15 \mathrm{~cm}$ stainless steel inlet line $(1.3 \mathrm{~cm}$ ID) topped with an in-house TSP (total suspended particulate) head.

\subsection{Inlet system for submicron aerosol measurements}

Ambient air was drawn through a $17.4 \mathrm{~m}$-long copper inlet line $\left(6.4 \mathrm{~mm}\right.$ internal diameter, flow rate $\left.10.6 \mathrm{~L} \mathrm{~min}^{-1}\right)$ installed across the rooftop of the research station at about $5 \mathrm{~m}$ above ground. The sampled air was then dried by passing through a Nafion $^{\mathrm{TM}}$ single tube counterflow dryer whose counterflow was dried additionally by a silica gel column. The average relative humidity of the sample flow was $26 \pm 5 \%$. After the dryer the flow was split to supply parallel sample flow to the SMPS and the AMS at 0.3 and $0.1 \mathrm{~L} \mathrm{~min}^{-1}$, respectively. Since the length of the inlet line and a long horizontal section of $7.8 \mathrm{~m}$ on the roof may have led to incomplete particle transmission due to diffusion, especially for particle sizes below $100 \mathrm{~nm}$, the particle losses were calculated with the Particle Loss Calculator of von der Weiden et al. (2009). From $13.7 \mathrm{~nm}$ (lower SMPS cut-off diameter) to $100 \mathrm{~nm}$ particle mobility diameter, the losses were estimated to decrease from $55 \%$ to $9 \%$. Between 100 and $735 \mathrm{~nm}$ (upper SMPS cut-off at $736.5 \mathrm{~nm}$ ), losses were estimated below $9 \%$, with a minimum near $300 \mathrm{~nm}$ at $4 \%$. For particle sizes greater than $735 \mathrm{~nm}$, losses were estimated to increase to $14 \%$ at $1000 \mathrm{~nm}$. These estimated losses were taken into account when calculating size distributions and total number concentrations from the SMPS measurements, since detailed information on the particle sizes were available. For the AMS-derived aerosol mass concentrations, the particle loss correction could not be applied because, even though the AMS was set to measure particle size 
Table 3. Continuous measurements of aerosol parameters, ammonia and meteorological data at the Bird Island research station.

\begin{tabular}{llll}
\hline Parameter & Instrument & Time resolution & Start/end date \\
\hline Ammonia & AiRRmonia & $15 \mathrm{~min}$ & $16 / 11-30 / 12 / 2010$ \\
\hline $\begin{array}{l}\text { Particle size distribution } \\
(11-624 \mathrm{~nm})\end{array}$ & $\begin{array}{l}\text { Scanning Mobility Particle } \\
\text { Sizer (SMPS) }\end{array}$ & $300 \mathrm{sec}$ & $15 / 11 /-28 / 12 / 2010$ \\
\hline $\begin{array}{l}\text { Particle size distribution } \\
(0.523-19.81 \mu \mathrm{m})\end{array}$ & $\begin{array}{l}\text { Aerodynamic Particle Sizer } \\
\text { (APS) }\end{array}$ & $300 \mathrm{~s}$ & $3 / 11-28 / 12 / 2010$ \\
\hline $\begin{array}{l}\text { Non-refractory aerosol } \\
\text { chemical composition } \\
\text { (submicron) }\end{array}$ & $\begin{array}{l}\text { Aerodyne high-resolution } \\
\text { time-of-flight aerosol mass }\end{array}$ & $300 \mathrm{~s}$ & $3 / 11-28 / 12 / 2010$ \\
& $\begin{array}{l}\text { spectrometer (HR-ToF-AMS, } \\
\text { AMS) }\end{array}$ & & \\
\hline $\begin{array}{l}\text { Meteorological data: wind } \\
\text { speed, wind direction, relative } \\
\text { humidity, pressure, minutes of } \\
\text { sunshine }\end{array}$ & British Antarctic Survey Bird & $60 \mathrm{~s}$ & continuous \\
\hline
\end{tabular}

distributions, the aerosol mass concentrations were mostly not high enough to derive a mass size distribution.

\subsection{Ammonia measurements}

Gas-phase ammonia was measured with an AiRRmonia wet chemistry analyser (RR Mechatronics). The instrument is designed for high time resolution continuous monitoring and is based on the principle of sampling gaseous $\mathrm{NH}_{3}$ into a stripping solution through a gas permeable Teflon membrane, with subsequent analysis of the liquid phase $\mathrm{NH}_{4}^{+}$via conductivity measurements. Particle-phase $\mathrm{NH}_{4}^{+}$is not retained by the membrane. The system's response time is between 10 and $15 \mathrm{~min}$, the detection limit is $0.1 \mu \mathrm{g} \mathrm{m}^{-3}$ and the accuracy $3 \%$ (Norman et al., 2009). Ambient air was sampled at $1 \mathrm{~L} \mathrm{~min}^{-1}$ through an insulated $2 \mathrm{~m}$-long polythene tube inlet at a height of $2 \mathrm{~m}$ above ground. By comparison, the approximate air-line distance to the AMS/SMPS inlet was $4 \mathrm{~m}$.

All instruments including operation details are listed in Table 3 .

\subsection{Further resources}

Meteorological parameters, such as temperature, wind speed, wind direction, pressure, relative humidity and minutes of sunshine, were provided by the British Antarctic Survey research facility's meteorological station at a time resolution of 1 min (see Fig. 2). The meteorological station was located one metre above the APS on the communications tower.

Back trajectories $240 \mathrm{~h}$ in duration were calculated with HYSPLIT (Draxler and Rolph, 2011) and started from the Bird Island research station at $54.008^{\circ} \mathrm{S}$ and $38.053^{\circ} \mathrm{W}$ at 00:00, 06:00, 12:00, and 18:00 UTC for the period between 3 November and 28 December 2010. Arrival altitudes were 10, 100 and $500 \mathrm{~m}$. Note that air mass back trajectory locations have an uncertainty of $15-30 \%$ of the distance between the start and end point.

Chlorophyll $a$ data provided by the MODIS Aqua satellite were obtained from the NASA Earth Observatory website (http://neo.sci.gsfc.nasa.gov/Search.html).

\section{Results and discussion}

\subsection{Overview of the Bird Island measurement results - aerosol chemical composition}

Measurements were taken throughout November and December 2010, when ambient temperatures started rising above $0{ }^{\circ} \mathrm{C}$. In Fig. 2 the basic meteorological data and total submicron aerosol number and mass concentrations for the measurement period are shown. Generally, the local wind direction was highly variable and only few periods with constant conditions were observed. This is most likely due to the influence of the local orography: the research station is surrounded by hills in all directions except towards the south where it faces the ocean. The main wind directions, as measured at the met station, were between $30^{\circ}$ and $70^{\circ}$, as well as $200^{\circ}$ and $240^{\circ}$. NE winds were observed frequently due to funnelling by a col between two hills (see Fig. 1) which is located to the NE of the station. Winds from the SW are channelled through the opening of the bay and by the steep slopes in the SE of the island. Locally measured wind speed reached up to $13.6 \mathrm{~m} \mathrm{~s}^{-1}$ with a median velocity of $4 \mathrm{~m} \mathrm{~s}^{-1}$. It snowed or rained nearly every day, with the exception of the first two weeks of November, which were exceptionally sunny and dry. The last day of the measurement period with a temperature below $0{ }^{\circ} \mathrm{C}$ was 13 November.

Table 4 shows basic statistics for sub- and super-micron aerosol. On average the mass concentration was $0.46 \mu \mathrm{g} \mathrm{m}^{-3}$, with a median of $0.40 \mu \mathrm{g} \mathrm{m}^{-3}$, and $96 \%$ of the data points 
Table 4. Basic statistics of submicron aerosol mass and number concentrations and super-micron particle number concentration (based on 5-minute measurements).

\begin{tabular}{lrrrrrr}
\hline Parameter & 10th percentile & 25th percentile & Median & 75th percentile & 90th percentile & Average \\
\hline $\begin{array}{l}\text { Submicron aerosol mass } \\
\text { concentration }\left(\mu \mathrm{g} \mathrm{m}^{-3}\right)\end{array}$ & 0.17 & 0.28 & 0.40 & 0.58 & 0.81 & 0.46 \\
\hline $\begin{array}{l}\text { Submicron aerosol number } \\
\text { concentration }\left(\mathrm{cm}^{-3}\right)\end{array}$ & 214 & 278 & 386 & 512 & 827 & 956 \\
\hline $\begin{array}{l}\text { Super-micron number } \\
\text { concentration }\left(\mathrm{cm}^{-3}\right)\end{array}$ & 1 & 3 & 8 & 14 & 19 & 9 \\
\hline
\end{tabular}

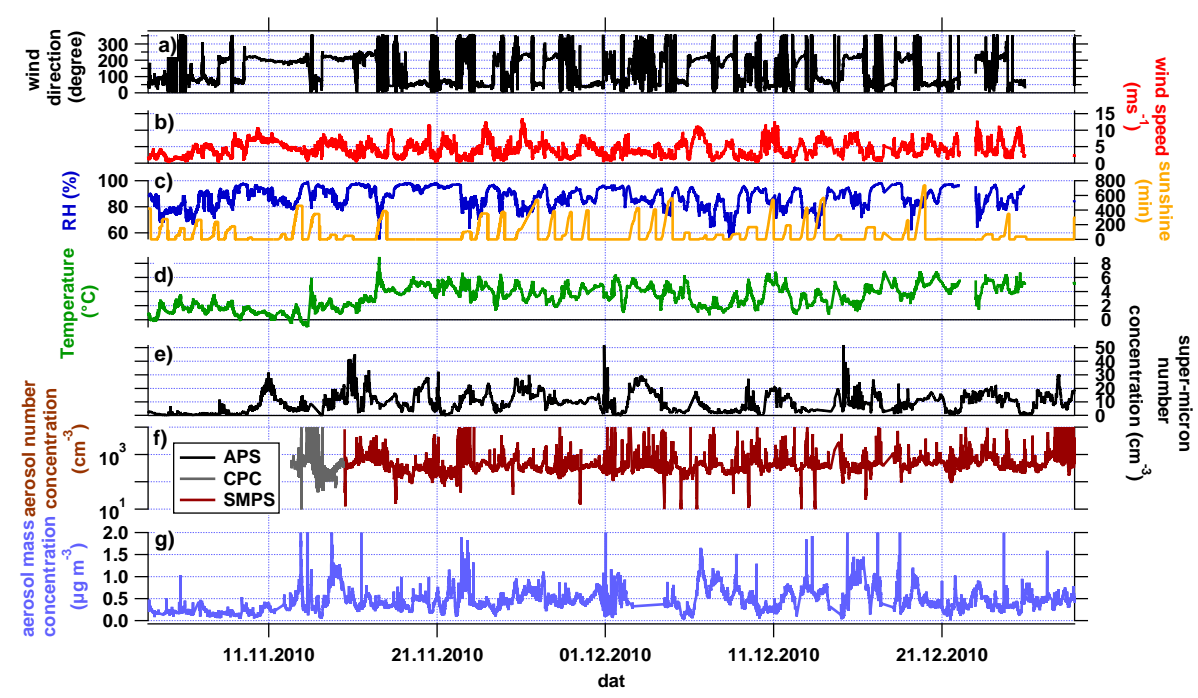

Fig. 2. (a-d) Meteorological data for Bird Island during the campaign from local measurements. The minutes of sunshine are accumulated for each day. (e) Super-micron aerosol number density measured by the APS, (f) submicron aerosol number density measured by a CPC and SMPS and (g) submicron aerosol mass concentration as derived by the AMS.

were $<1.00 \mu \mathrm{g} \mathrm{m}^{-3}$. The submicron number density was much more variable, as shown by the large difference between the average $\left(956 \mathrm{~cm}^{-3}\right)$ and the median $\left(386 \mathrm{~cm}^{-3}\right)$ concentrations. A total of $75 \%$ of the 5 min data points were $<530 \mathrm{~cm}^{-3}$. Super-micron aerosol number density, most likely dominated by sea spray particles, was much lower with an average of $9 \mathrm{~cm}^{-3}$.

Generally, the Bird Island aerosol detected by the AMS (i.e. the non-refractory $\mathrm{PM}_{1}$ ) was dominated by particulate sulfate (46\%; see Fig. 3a) as expected based on earlier studies (e.g. Quinn et al., 1998). It originated from three sources: sea salt, dimethylsulfid (DMS) and long-range transport, as is elaborated upon in Sect. 3.9. Based on laboratory experiments with Sigma-Aldrich sea salt standard S9883 (in which ss- $\mathrm{SO}_{4}^{2-}$ corresponds to $13.8 \%$ of sea salt chloride mass according to the composition data sheet), the AMS detected a

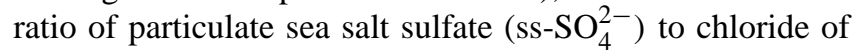
$63 \%$. For the aerosol on Bird Island, this implies that the median ss- $\mathrm{SO}_{4}^{2-}$ contribution to total $\mathrm{PM}_{1}$ particulate sulfate was $10.8 \%$ (4.6-21.4\% within the inter-quartiles), based on the ss- $\mathrm{Cl}^{-}$determination described in the Supplement. Large variations occurred during periods with strong methanesulfonic acid (MSA) contribution, which are discussed further in Sect. 3.6. Organic matter contributed nearly $38 \%$ to the mass, followed by $\mathrm{NH}_{4}^{+}(12 \%)$ and $\mathrm{NO}_{3}^{-}(4 \%)$; see Fig. 3a. The chemical makeup of the organic mass contribution is discussed in detail in Sect. 3.4, where the results of the positive matrix factorisation analysis are described. The nitrate concentration was expected to be small, since the only sources that emitted $\mathrm{NO}_{\mathrm{x}}$ locally were the station's power generator and the kitchen stove. $\mathrm{NO}_{\mathrm{x}}$ can be converted to nitric acid $\left(\mathrm{HNO}_{3}\right)$, allowing nitrate to partition into the particle phase. However, because of the slow timescale of this process this would have affected local $\mathrm{NO}_{3}^{-}$concentrations only during conditions of stagnant or re-circulating air. The relatively high $\mathrm{NH}_{4}^{+}$fraction was probably due to several sources: the open ocean itself has been observed to potentially be both a sink and a source of ammonia at high southern latitudes (Johnson et al., 2008), but is likely close to equilibrium and highly influenced by local biogeochemical cycles 

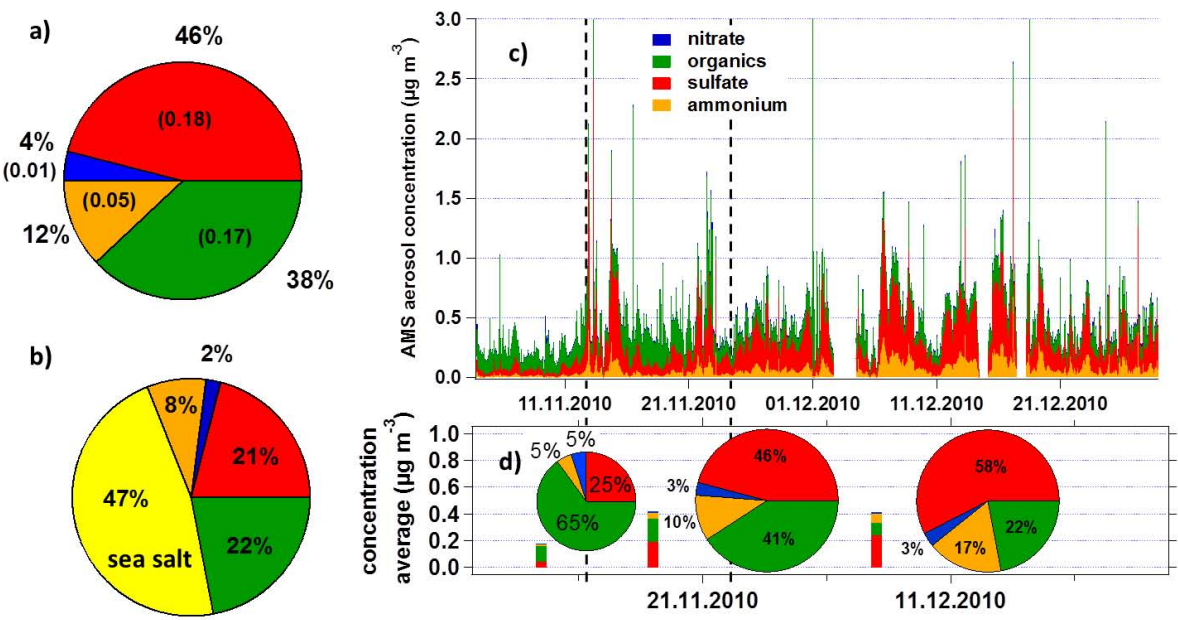

Fig. 3. (a) Average mass contribution of individual chemical species (the numbers in parentheses indicate the average mass concentration in $\mu \mathrm{g} \mathrm{m}^{-3}$ ). (b) Average mass contribution of individual chemical species including sea salt, up-scaled from the $\mathrm{NaCl}^{+}$signal based on Ovadnevaite et al. (2012). (c) Stacked time series of AMS-measured aerosol mass concentrations. (d) Average mass concentration for three time periods (3-12 November, 12-22 November, 22 November-28 December, indicated by the dashed vertical bars) and the respective relative composition (the area of the pie charts reflects the overall concentration).

and long-range transport. Bird Island, South Georgia and the neighbouring rocky islands (e.g. Willis Island) are large local ammonia sources due to the decomposition of uric acid in the excreta from fur seals and seabirds. Ornithogenic soils may also be a source at times (Legrand et al., 1998, 2012; Zhu et al., 2011). When accounting for sea salt based on the method proposed by Ovadnevaite et al. (2012), concentrations in the submicron aerosol composition change to $21 \%$ nss- $\mathrm{SO}_{4}^{2-}$, $2 \% \mathrm{NO}_{3}^{-}, 8 \% \mathrm{NH}_{4}^{+}, 22 \%$ Org and $47 \%$ sea salt (including ss- $\mathrm{SO}_{4}^{2-}$ ); see Fig. 3b. Diurnal patterns were not observed for any aerosol species.

Figure $3 \mathrm{c}$ shows the time series of the standard AMS chemical components of Bird Island aerosol divided into three periods (P1: 3 to 12 November, P2: 13 to 22 November, P3: 23 November to 28 December). During P1, the average mass concentration was $0.20 \mu \mathrm{g} \mathrm{m}^{-3}$, while during P2 and P3 it was $0.48 \mu \mathrm{g} \mathrm{m}^{-3}$ (see Fig. 3d). This coincides with a general change in temperature (see Fig. 2d) from $1.3{ }^{\circ} \mathrm{C}$ on average during the first period to $3.8^{\circ} \mathrm{C}$ on average after November 12th. However, there is no clear indication that the temperature change and the aerosol mass concentration are related. The same three periods can also be differentiated chemically. While particulate organics dominate during P1 at $59 \%$, their contribution decreases to $35 \%$ and $19 \%$ for the later periods, respectively. By contrast, particulate $\mathrm{SO}_{4}^{2}$ contribution is the opposite: accounting for $23 \%$ in P1 then increasing to a contribution of $40 \%$ and finally $50 \%$. The lower aerosol mass concentration during the first period may be explained by a lower contribution from particulate sulfate (see Fig. 3d). The main source of this component is probably MSA, whose contribution was very low during the first two periods (see Fig. 5). Periods of low particulate sulfate concentration correspond with low concentrations of aerosol ammonium. Both species increase by a factor of 4.3 and 4.6, respectively, between $\mathrm{P} 1$ and $\mathrm{P} 2$, and by factor of 5.4 and 7.6 between P1 and P3. Another reason for the lower aerosol mass concentration is the smaller contribution by chloride and sea salt components leading to lower particulate sulfate mass concentrations as well. These species contribute by a factor 3.6-3.8 more during the later measurement periods, which may be related to the, on average, lower wind speeds during P1 (see Fig. 2d). This is also reflected by the low super-micron particle number concentrations (see Fig. 2e).

\subsection{Aerosol acidity}

Since ambient $\mathrm{NH}_{3}$ was available in large concentrations (up to $350 \mu \mathrm{g} \mathrm{m}^{-3}$ measured in the atmosphere at the research station (unpublished data), ammonium could partition into the particle phase to neutralise the sulfuric acid. Such high concentrations of ammonia (from 20 to $100 \mu \mathrm{g} \mathrm{m}^{-3}$ ) were also measured in summer at the Dumont d'Urville site located on the Ile des Pétrels at the East Antarctic coast $\left(66^{\circ} \mathrm{S}\right)$ where 15000 breeding pairs of Adélie penguins are living (Legrand et al., 2012). It was assumed that chloride and $\mathrm{ss}^{-} \mathrm{SO}_{4}^{2-}$ were already neutralised by sea salt cations while particulate nitrate and nss- $\mathrm{SO}_{4}^{2-}$ were neutralised by reaction with gas-phase ammonia. To derive aerosol acidity, the stochiometric ratio of ammonium and sulfate ions was calculated, where a ratio of $2: 1$ represents fully neutralised $\left(\mathrm{NH}_{4}\right)_{2} \mathrm{SO}_{4}$, a ratio of $1: 1$ reflects the formation of ammonium bisulfate $\left(\mathrm{NH}_{4} \mathrm{HSO}_{4}\right)$, and a ratio of $<1: 1$ means presence of sulfuric acid. During the measurement period, on average, during $12 \%$ of the time particulate sulfate was fully 


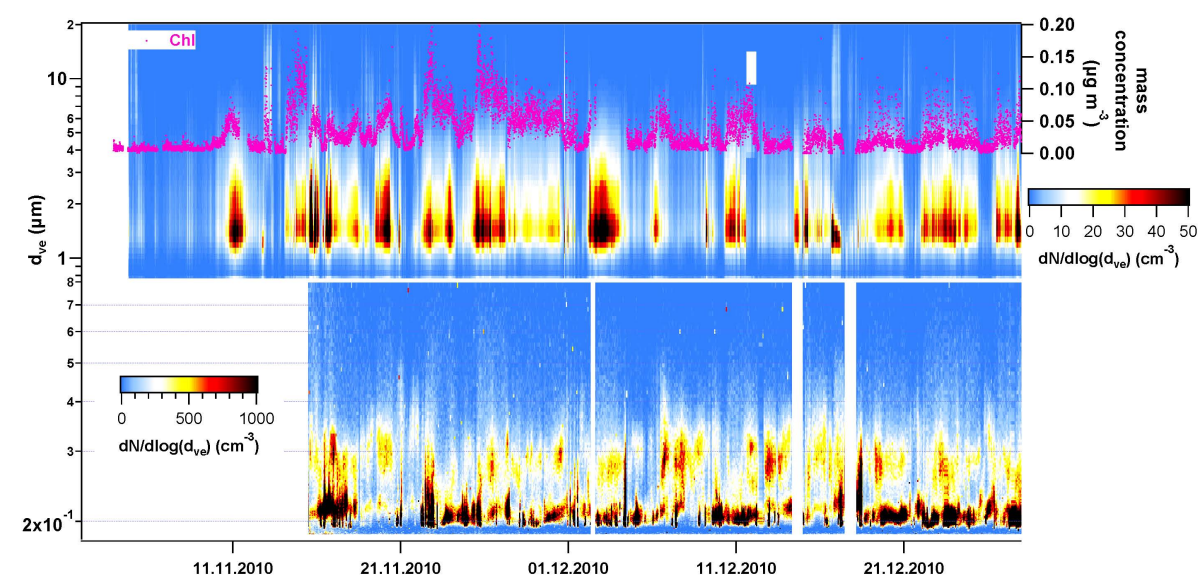

Fig. 4. Time series of SMPS (bottom) and APS (top) number size distribution measurements in $\mathrm{d} N / \mathrm{d} \log \left(d_{\mathrm{ve}}\right)$. In the upper panel also the time series of particulate chloride is shown.

neutralised, while during $79 \%$ of the time sulfate particles contained a mixture of ammonium sulfate and ammonium bisulfate, and during $9 \%$ of the time particles contained sulfuric acid. This finding differs from other observations of marine aerosol. For example, Phinney et al. (2006) and Zorn et al. (2008) found that marine aerosol was rather acidic, with $60 \%$ of the sulfate in form of sulfuric acid, both in the subArctic and in sub-Antarctica, while Quinn et al. (2006) found marine aerosol with $78 \%$ and $85 \%$ of the sulfate in form of sulfuric acid. For the coastal Antarctic site of Neumayer located at $70^{\circ} \mathrm{S}$ facing the South Atlantic ocean and free of penguin colonies, Legrand et al. (1988) reported a typical ratio of ammonium to non-sea-salt sulfate close to $2 \%$, pointing out the very acidic nature of non-sea-salt sulfate aerosol there.

\subsection{Aerosol size distributions}

Figure 4 shows the time series of the number size distributions measured by the SMPS and the APS. For SMPS data, where the particle diameter is given as $d_{\text {mob }}$, it was assumed that $d_{\text {mob }}$ is equivalent to the volume-equivalent diameter of the particles $\left(d_{\mathrm{ve}}\right)$. APS size distributions are a function of the aerodynamic diameter $d_{\mathrm{a}}$. Diameter $d_{\mathrm{a}}$ was converted to $d_{\mathrm{ve}}$ according to Eq. (5), after DeCarlo et al. (2004):

$d_{\mathrm{ve}}=d_{\mathrm{a}} \cdot \sqrt{\chi \cdot \frac{\rho_{0}}{\rho_{\mathrm{s}}}}$,

with $\chi=1.00$ shape factor of sea salt (DeCarlo et al., 2004); $\rho_{\mathrm{o}}=1$ unit density in $\mathrm{g} \mathrm{cm}^{-3}$; and $\rho_{\mathrm{s}}=2.17 \mathrm{~g} \mathrm{~cm}^{-3}$ density of sodium chloride. The Cunningham slip correction factor was assumed to be 1 . The sea salt shape factor was set to 1.00 because we assume that the particles were close to spherical since the APS sample flow was not dried.

Three size modes were observed: one showing up in the particle number size distribution at $d_{\mathrm{mob}}<100 \mathrm{~nm}$, a second one between 100 and $400 \mathrm{~nm}$ and a third one between 1 and $2 \mu \mathrm{m}$. The coarsest mode is associated with sea salt particles, which are generally expected to be in the super-micron size range (e.g. Cavalli et al., 2004).

Even though the AMS chloride represents only the submicron fraction, this chemical species turns out to be a good proxy for the super-micron sea salt mode: chloride concentrations co-vary with the super-micron particle number density, confirming that at this site the AMS $\mathrm{Cl}^{-}$is dominated by sea salt and not by $\mathrm{NH}_{4} \mathrm{Cl}$ as is usually thought to be the case at more continental sites (Canagaratna et al., 2007).

The campaign average size distributions of particulate sulfate and ammonium derived from the AMS measurements were calculated from 80 to $800 \mathrm{~nm} d_{\mathrm{va}}$ in 40 bins. The size distributions indicate that ammonium was internally mixed with sulfate. When fitting the particulate sulfate mass distribution with a bimodal log-normal function, the mode diameters were $270 \pm 2 \mathrm{~nm}$ and $354 \pm 8 \mathrm{~nm}$, with geometric standard deviations of $1.3 \pm 1.0$ and $1.7 \pm 1.0$, respectively The tail towards the larger diameters might result from contributions of larger sea salt sulfate particles and their slower evaporation in the AMS. Size distributions for nitrate, organics, and chloride could not be obtained from the AMS data due to low signal to noise ratios. Instead, size distributions derived from SMPS measurements, related to individual OA factors, were determined by the PMF analysis (see Sect. 3.4 for details).

\subsection{Speciated contributions of particulate organics to the marine aerosol - PMF results}

Application of the PMF method indicates that the organic aerosol measured at Bird Island can be attributed to five specific aerosol source types (factors). We refer the reader to the supplementary material for a detailed discussion regarding the selection of the 5-factor solution which is presented 

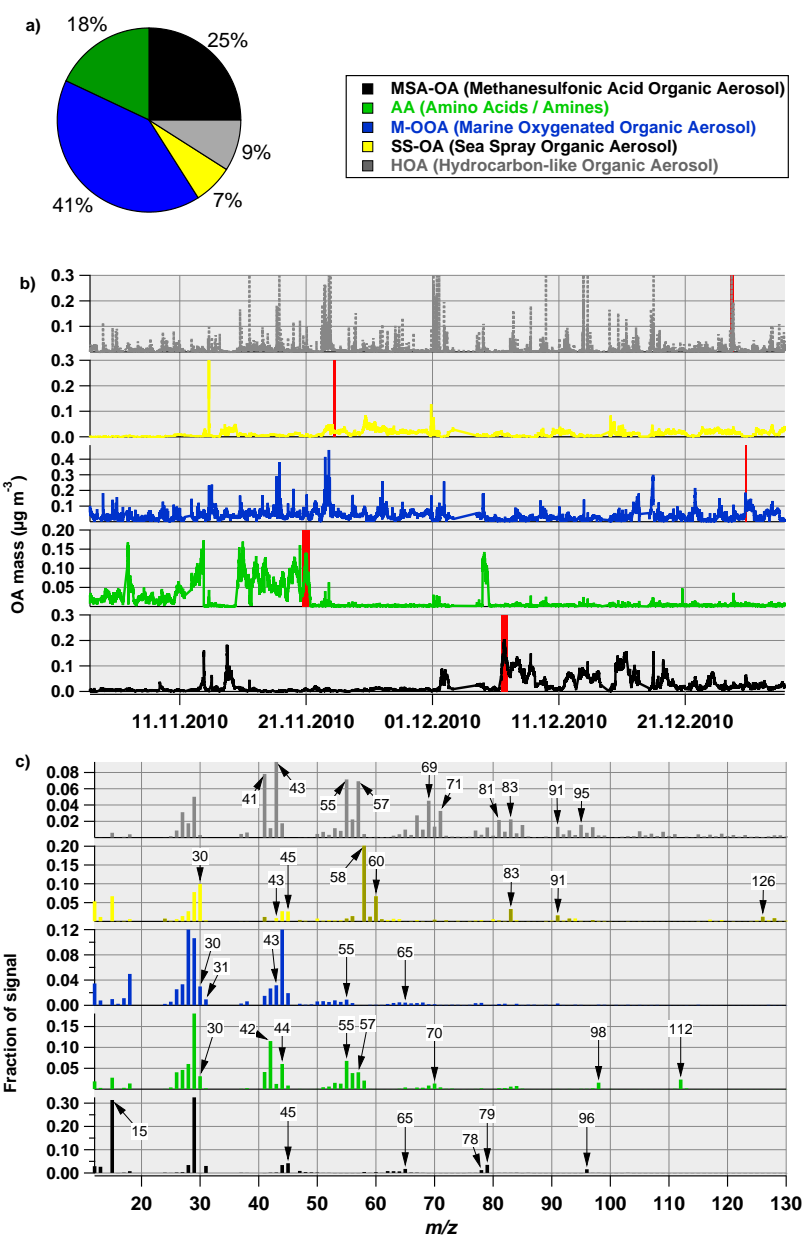

Fig. 5. Suggested 5-factor PMF solution for Bird Island organic aerosol: (a) pie chart of relative contributions per factor without salt ion fragments, (b) time series and (c) mass spectrum for each factor. The red vertical bars in (b) indicate the time periods used for HR PIKA analysis. The olive-coloured bars in (c) indicate $\mathrm{m} / \mathrm{z}$ with major inorganic contributions.

in Fig. 5. Table 6 summarises all correlations of mass spectra and time series for the chosen factors that were used to validate the solution.

The HOA (hydrocarbon-like organic aerosol) factor originated from the research station diesel generator and contributed on average $9 \%$ to the OA mass. HOA aerosol fragments are frequently observed when there are fresh emissions of incomplete combustion (e.g. Zhang et al., 2005). The diesel generator is the research facility's only power supply and was thus continuously operated. It is located at an angle between $240^{\circ}$ and $270^{\circ}$ with an approximate distance between the generator and the sampling inlet of $30 \mathrm{~m}$. Correlation with the average HOA mass spectrum from 15 different measurements reported by $\mathrm{Ng}$ et al. (2011) was high with $R^{2}=0.98$. The M-OOA (marine oxygenated organic aerosol) factor contributed on average $41 \%$ to the
OA mass. In addition, three further OA species were identified. Methanesulfonic acid organic aerosol (MSA-OA) contributed $25 \%$ of the organic matter. Sulfur contained in the inorganic sulfate particles that also originate from MSA emissions are not accounted for here. The third-largest signal, with $18 \%$, was attributed to a factor called amino acid/amine (AA), due to the nitrogen-containing marker ions identified (ion fragment and exact mass in parentheses): $m / z 30\left(\mathrm{CH}_{4} \mathrm{~N}^{+}, 30.03\right), m / z 42\left(\mathrm{C}_{2} \mathrm{H}_{4} \mathrm{~N}^{+}, 42.03\right), m / z 58$ $\left(\mathrm{C}_{3} \mathrm{H}_{8} \mathrm{~N}^{+}, 58.06\right)$ and $86\left(\mathrm{C}_{5} \mathrm{H}_{12} \mathrm{~N}^{+}, 86.10\right)$. The fragments at $m / z 30$ and 42, in particular, have been identified as amino acid makers before (Schneider et al., 2011). The other two ion fragments have also been observed previously and are also indicators for amines (Hildebrandt et al., 2011). The fifth OA source correlates with sea salt and contributed $7 \%$ to the organic aerosol mass. This was derived from the 5th identified PMF factor, whose mass spectrum was found to still contain non-organic fragments that had not been accounted for in the fragmentation table. These are listed in Table 3 and include, e.g., $m / z 58\left(\mathrm{NaCl}^{+}\right)$and its isotope at $m / z 60$ which dominate the mass spectrum. High-resolution analysis was used to separate these inorganic sea salt contributions from the sea spray organics, as discussed in Sect. 3.7. So the relative contributions as shown in the pie chart and the time series in Fig. 5a and b only refer to organic sea spray aerosol mass (SS-OA) without inorganic salt ion fragments, whereas the mass spectrum (Fig. 5c) also represents the contributions from sea salt in a different colour, as determined by the PMF analysis.

In addition, for all PMF factors average volume size distributions were calculated based on the SMPS data, for time intervals when the respective factor dominated the mass spectrum, accounting for 66 to $85 \%$ of the mass (with the exception of sea spray at $50 \%$ ). The time intervals are marked in red in Fig. 5b. The results are discussed in the respective sections for each PMF factor. For the factors SS-OA, MSA-OA and AA super-micron total volume size distributions derived from the APS for the same time intervals as marked in Fig. 5b are shown for comparison (see Fig. 6 and Table 5). Again $d_{\mathrm{a}}$ was converted to $d_{\mathrm{ve}}$.

\subsection{Back trajectory analysis}

To investigate the extent to which the different PMF factors were related to local sources or long-range transported air masses, back trajectories were calculated for three arrival altitudes $(10,100,500 \mathrm{~m})$ as shown in Fig. 7a. The back trajectories were then allocated to one of four trajectory clusters (Antarctica, Ocean, West, and South America), for which the average mass concentrations, including one standard deviation, were calculated. Note that there is no significant difference when attributing either the $240 \mathrm{~h}$ - or $120 \mathrm{~h}$-long back trajectories to the clusters. The trajectories were attributed to the four clusters as follows: in the cluster "Antarctica" the trajectories originated from Antarctica and did not pass over any 
Table 5. Fit parameters of the log-normal volume size distributions for each PMF factor*.

\begin{tabular}{|c|c|c|c|c|c|c|c|c|c|}
\hline Factor & $V_{0}$ & $d_{\mathrm{p}_{0}}(\mu \mathrm{m})$ & $\sigma_{g_{0}}$ & $V_{1}$ & $d_{\mathrm{p}_{1}}(\mu \mathrm{m})$ & $\sigma_{\mathrm{g}_{1}}$ & $V_{\mathrm{s}}$ & $d_{\mathrm{p}_{\mathrm{s}}}(\mu \mathrm{m})$ & $\sigma_{\mathrm{g}_{\mathrm{s}}}$ \\
\hline MSA-OA & $2.61 \pm 0.04$ & $0.38 \pm 0.01$ & $1.56 \pm 1.01$ & $0.18 \pm 0.02$ & $0.72 \pm 0.01$ & $1.07 \pm 1.01$ & $26.03 \pm 0.37$ & $7.28 \pm 0.08$ & $1.90 \pm 0.42$ \\
\hline AA & $0.57 \pm 0.12$ & $0.29 \pm 0.01$ & $1.32 \pm 1.07$ & $9.84 \pm 6.91$ & $0.71 \pm 1.61$ & $1.28 \pm 0.63$ & $34.61 \pm 0.49$ & $5.41 \pm 0.60$ & $1.97 \pm 0.04$ \\
\hline M-OOA & $0.70 \pm 0.04$ & $0.36 \pm 0.01$ & $1.33 \pm 1.02$ & $0.80 \pm 0.14$ & $0.44 \pm 0.06$ & $2.73 \pm 1.20$ & & & \\
\hline SS-OA & $2.04 \pm 0.44$ & $0.43 \pm 0.12$ & $2.10 \pm 1.25$ & $1.36 \pm 0.45$ & $0.65 \pm 0.02$ & $1.31 \pm 1.06$ & $54.50 \pm 1.53$ & $4.96 \pm 0.05$ & $1.3 \pm 0.04$ \\
\hline $\mathrm{HOA}$ & $0.66 \pm 0.06$ & $0.32 \pm 0.01$ & $1.45 \pm 1.07$ & $1.29 \pm 0.06$ & $0.55 \pm 0.01$ & $1.38 \pm 1.032$ & & & \\
\hline
\end{tabular}

* Fit function: $\frac{\mathrm{d} V}{\operatorname{d} \ln \left(d_{\mathrm{p}}\right)}=\frac{V_{i}}{\sqrt{2 \pi} \cdot \ln \left(\sigma_{g_{i}}\right)} \cdot \exp \left\{-\left(\frac{\left(\ln \frac{d_{\mathrm{p}}}{d_{\mathrm{p}_{i}}}\right)^{2}}{2 \cdot\left(\ln \left(\sigma_{g_{i}}\right)\right)^{2}}\right)\right\}$

with $V$ standing for volume $\left(\mu \mathrm{m}^{3} \mathrm{~cm}^{-3}\right), d_{\mathrm{p}}$ for the particle aerodynamic diameter $d_{\mathrm{a}}$ in $\mu \mathrm{m}, d_{\mathrm{p}_{i}}$ is the geometric mean diameter in $\mu \mathrm{m}$ of the respective mode, and $\sigma_{\mathrm{g}_{i}}$ is the geometric standard deviation of each mode.

Fit parameters with number indices ( 0 and 1$)$ were fit to the SMPS size distributions while fit parameters with the index s where fit to the super-micron size distributions measured by the APS.

other land surface. The "Ocean" cluster consisted of trajectories that spent most of their lifetime over the ocean, with no or only a short residence period over Antarctica. The cluster "West" included all trajectories that passed over South America between Cape Horn and Puerto Montt $\left(56^{\circ}\right.$ to $44^{\circ} \mathrm{S}$ ), a scarcely inhabited area, but with some mining activities. Finally, the cluster "South America" describes all trajectories that passed over the continent north of Puerto Montt, a more densely inhabited region than the West cluster. Figure $7 \mathrm{~b}$ illustrates the four cluster maps for an arrival height of $100 \mathrm{~m}$. The numbers indicate the number of trajectories in each cluster with the arrival height in parentheses. No significant difference between the three arrival heights was found. For the HOA and sea spray factors, no clear pattern associated with air mass origin could be isolated (Fig. 7a). This is not surprising in the case of HOA, since this factor was identified as local pollution, as mentioned above. Figure $7 \mathrm{c}$ shows that HOA was primarily observed when the wind came from the southwest, with the grey area indicating the inter-quartiles of the HOA concentration, while the boxes represent the mean concentration in $\mu \mathrm{g} \mathrm{m}^{-3}$. The station's generator was located at about $255^{\circ}$, and the kitchen's chimney near $280^{\circ}$. Any other potential sources, such as the nearest stationary generator located more than $150 \mathrm{~km}$ to the east on South Georgia or any ships present in the wider area, would not have produced the fresh HOA time series as observed. Signals from plumes of passing or anchored ships near Bird Island were not observed in the data.

For sea spray, the source is ubiquitous and is expected to be a function of wind speed and direction rather than due to long-range transport, as is shown in Sect. 3.7. For the amino acid/amine factor, long-range transport from a defined region can also be excluded. There may be a tendency for concentrations to be elevated in oceanic air masses. This however is not statistically significant, as is indicated by the error bars that represent one standard deviation (Fig. 7a). More details on the origin of the AA factor are discussed in Sect. 3.8. MSA-OA, however, seems to have been transported from the south (Antarctic region) towards Bird Island. The MSA-OA

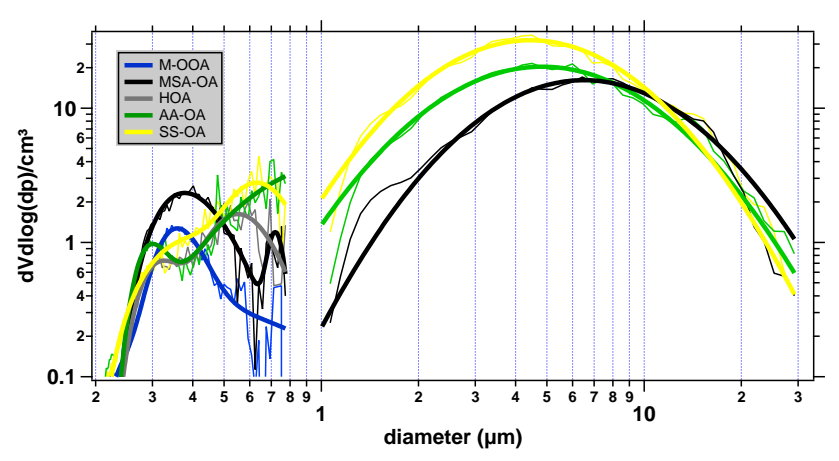

Fig. 6. Volume size distributions derived for individual PMF OA factors by the SMPS (a) and APS (b). The data were extracted from the time periods during which the respective factors dominated the submicron organic mass (> $66 \%$, and $50 \%$ for SS-OA), indicated by the red bars in Fig. $5 b$. The thinner lines represent the actual data, while the thicker lines show the fits to the data (see Table 5).

concentration in the Antarctica and Ocean cluster air masses can be distinguished clearly. By contrast, concentrations of M-OOA appear to have been reduced in air masses originating from Antarctica, allowing for the possibility that anthropogenic oxygenated aerosol may play a role, in addition to marine oxygenated aerosol (see Sect. 3.9).

\subsection{Methanesulphonic acid organic aerosol}

Although the correlation coefficient with the AMS database MSA-OA laboratory reference spectrum (L_STD_Q_027_MSA) after Phinney et al. (2006), $R^{2}=0.14$, and with the $600^{\circ} \mathrm{C}$ spectrum reported by Zorn et al. (2008), $R^{2}=0.32$, are rather low, this factor profile contains the typical MSA-OA marker fragments at $\mathrm{m} / \mathrm{z}$ $44.98 \mathrm{CHS}^{+}, 47.00 \mathrm{CH}_{3} \mathrm{~S}^{+}, 64.97 \mathrm{HSO}_{2}^{+}, 77.98 \mathrm{CH}_{2} \mathrm{SO}_{2}^{+}$, $77.99 \mathrm{CH}_{3} \mathrm{SO}_{2}^{+}$, and $95.99 \mathrm{CH}_{4} \mathrm{SO}_{3}^{+}$(see Fig. 5c). Three of the marker ions are shown in high resolution in Fig. 8. The poor correlation may be a result of comparing a laboratory standard spectrum with ambient measurements. 


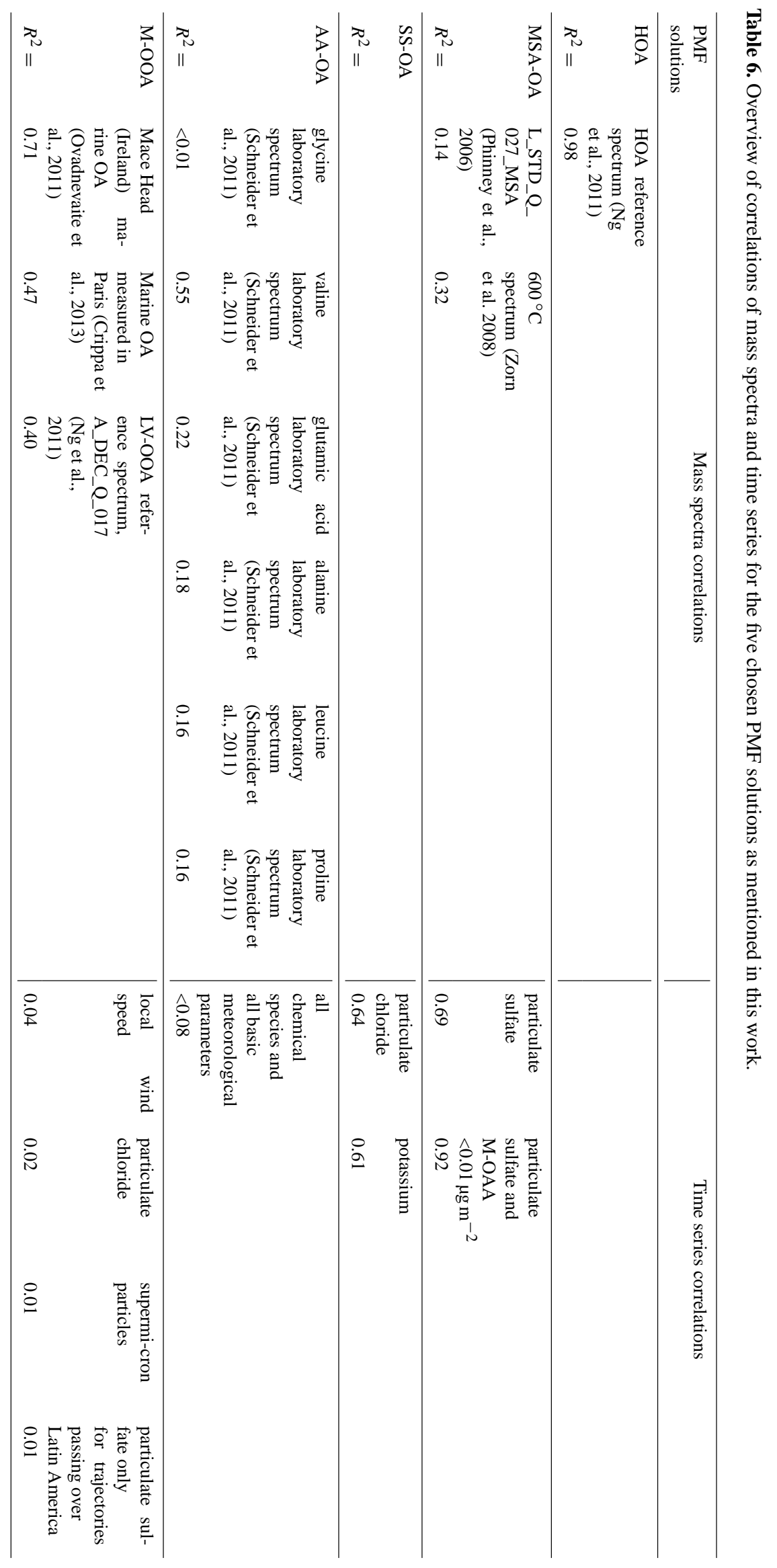



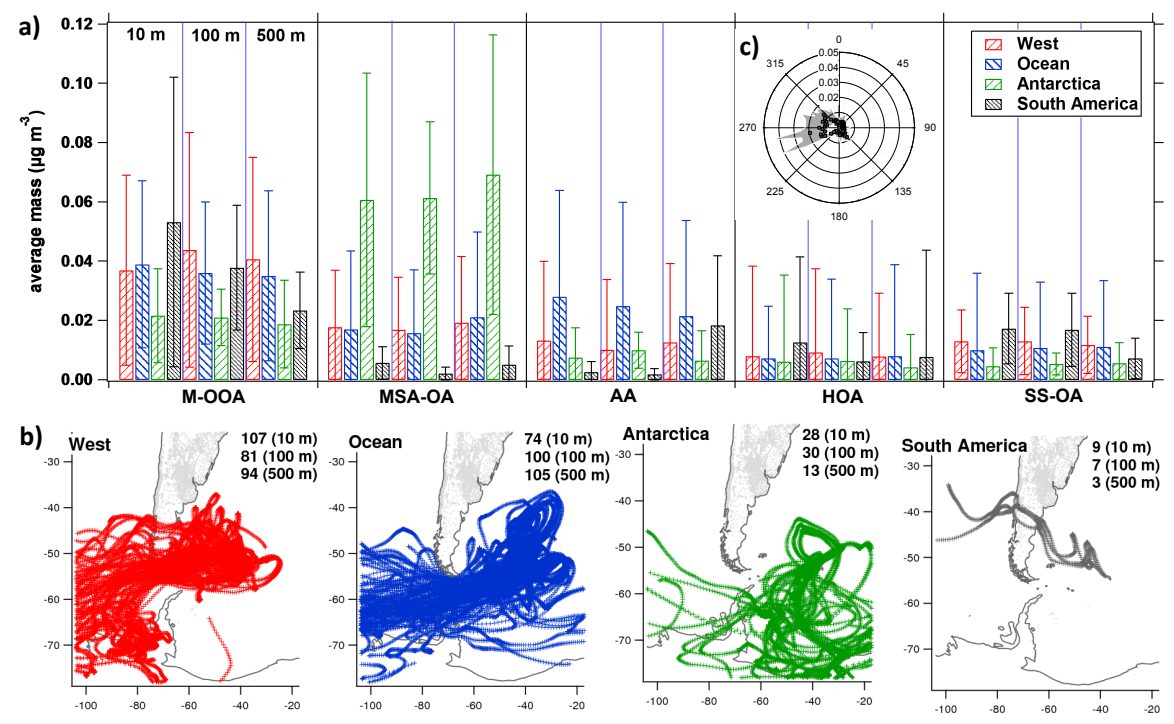

Fig. 7. (a) Average mass concentration and standard deviation for each PMF factor sorted by back trajectory cluster. (b) Example at $100 \mathrm{~m}$ altitude back trajectory release height for each cluster. The numbers indicate the number of trajectories allocated to the specific cluster with the release heights in parentheses. (c) Wind rose for the PMF HOA factor. The grey shaded area represents the inter-quartiles of HOA concentration in $\mu \mathrm{g} \mathrm{m}^{-3}$ while the boxes indicate the mean concentration.
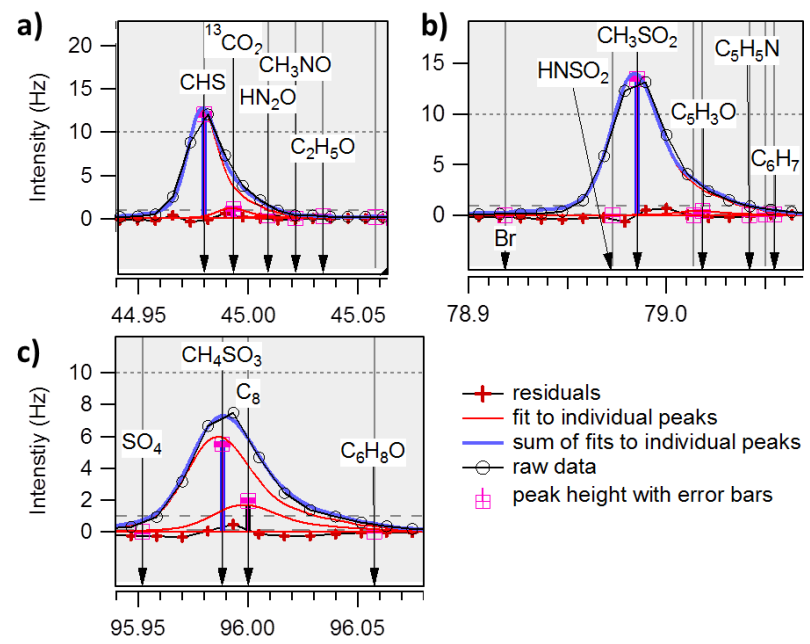

- residuals

fit to individual peaks _ sum of fits to individual peaks $\smile$ raw data

由 peak height with error bars

Fig. 8. Selection of high-resolution marker ion fragments for methanesulfonic acid $\mathrm{OA}$ in the difference spectrum.

A further indication for this factor to represent MSAOA is the high correlation with the AMS particulate sulfate measurements, $R^{2}=0.69$. When dimethyl sulfide is emitted by phytoplankton, it is oxidised either to MSA or to sulfur dioxide and sulfuric acid, which will in turn partition into the particulate phase (Seinfeld and Pandis, 2006). Thus, a correlation between particulate MSA-OA and sulfate is expected as shown in Fig. 9. We used 8-day average chlorophyll $a$ observations from the Moderate Resolution Imaging Spectroradiometer (MODIS) satellite data (http://neo.sci.

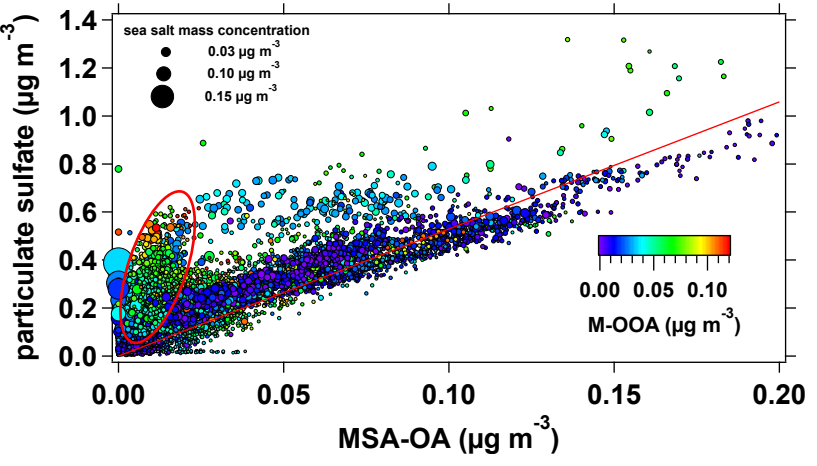

Fig. 9. Correlation between particulate sulfate and methanesulfonic acid OA mass concentration, colour-coded by the mass concentration of the PMF M-OOA factor. The size of the marker represents the amount of sea salt. The red ellipse indicates a cluster of points that might be affected by long-range transport. The red line represents the linear regression between particulate sulfate and MSA-OA when M-OOA $<0.01 \mathrm{\mu g} \mathrm{m}^{-3}$ (slope $=5.3 \pm 0.03, R^{2}=0.92$ ).

gsfc.nasa.gov/Search.html) as an indicator for phytoplankton activity around Bird Island. The plankton bloom onset in the $10^{\circ} \times 10^{\circ}$ square around Bird Island $\left(49-59^{\circ} \mathrm{S}\right.$ and $33-43^{\circ} \mathrm{W}$ ) happened in late September 2010, where the average chlorophyll $a$ concentration was $0.28 \mathrm{mg} \mathrm{m}^{-3}$. During the AMS measurement period concentrations increased from 0.62 to $0.85 \mathrm{mg} \mathrm{m}^{-3}$ until 24 November and then decreased to $0.49 \mathrm{mg} \mathrm{m}^{-3}$ by 31 December. This indicates that the AMS measurements covered the seasonal peak in MSA emissions. In addition, back trajectory analysis revealed that MSA-OA 

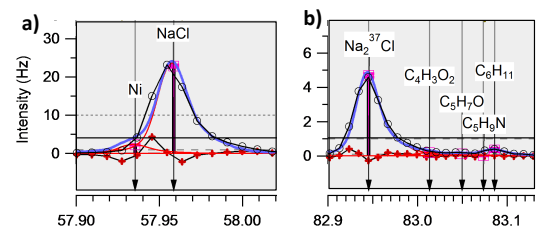

+ residuals

— sum of fits to individual peaks

$\odot$ raw data

由 peak height with error bars
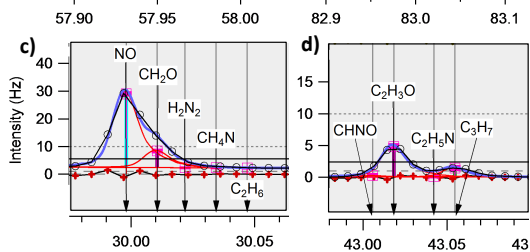

- fit to individual peaks

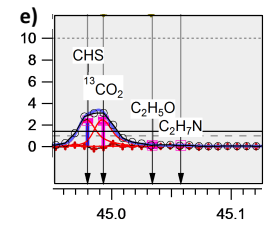

Fig. 10. HR ion fragment fits for two inorganic species and 3 organic species of the sea spray PMF factor in the difference spectrum.

was primarily advected from the southern Antarctica cluster including the region around South Georgia, a location where plankton booms are often observed by satellite (Korb and Whitehouse, 2004; Korb et al., 2004, 2008). The lower envelop of the relationship between sulfate and MSA-OA (Fig. 9) shows a slope close to 5.3 (i.e. a ratio of MSA-OA to particulate sulfate close to $19 \%$ ). This value of the MSAto-sulfate ratio likely corresponds to air masses that were not long-range transported and correspond to quasi-pure marine DMS oxidation in these regions. This value lies between the low values observed at low latitudes (less than $10 \%$; Saltzman et al., 1983) and the higher ones observed at coastal Antarctic sites $(30 \%$ at the Dumont d'Urville site; Jourdain and Legrand, 2001). Other studies, such as by Sciare et al. (2009), have shown the importance of marine biological activity related to chlorophyll observations in organic aerosol before.

MSA-OA aerosol exhibits two volume size distribution modes in the submicron particle fraction, with mode diameters at $240 \pm 10$ and $650 \pm 10 \mathrm{~nm}$ and another mode in the super-micron fraction at $7.28 \pm 0.08 \mu \mathrm{m}$ (see Fig. 6).

\subsection{Sea spray organic factor}

The qualitative PMF sea spray factor is dominated by $\mathrm{m} / \mathrm{z}$ 57.96 and 59.96, which represent $\mathrm{Na}^{35} \mathrm{Cl}^{+}$and the isotopologue $\mathrm{Na}^{37} \mathrm{Cl}^{+}$, and which is characterised by a number of other inorganic ion fragments, such as $m / z 90.90 \mathrm{FeCl}$, 125.87 $\mathrm{FeCl}_{2}$, and $127.87 \mathrm{Fe}^{37} \mathrm{ClCl}$ (all marked in olive in Fig. $5 \mathrm{c}$ ). The average ratio of the two sodium chloride isotopologues measured throughout the campaign was 3.1, as was expected for sea salt (De Laeter et al., 2003). The iron chloride ions were most likely an artefact, a result of reactions of the AMS heater material with sea salt during unusually high exposure on Bird Island. Fragments such as $\mathrm{Na}^{+}$ $(m / z 22.98), \mathrm{Mg}^{+}$(23.98) or $\mathrm{K}^{+}$(38.96) are not part of the spectrum, as they were not included in the input matrix.

Several studies reveal that sea spray aerosol contains organic matter of different origins in the submicron mode (e.g.
Cavalli et al., 2004; O'Dowd et al., 2004; Facchini et al., 2008a; Russell et al., 2010; Gaston et al., 2011; Lapina et al., 2011; Shank et al., 2012). To determine how much mass within the Bird Island sea spray organic aerosol factor can be attributed to organic components, HR PIKA analysis was applied to the total AMS spectrum during a period with dominant PMF sea spray factor contribution on 24 December (see red bar in Fig. 5b). About $59 \%$ of the mass of this factor is contributed by organic matter (SS-OA), while $41 \%$ are associated with inorganic salts. Figure 10 shows a selection of HR fitted ion fragments that are representative for the sea spray factor. Panel (a) shows the most dominant fragment $\left(\mathrm{Na}^{35} \mathrm{Cl}^{+}\right.$), while Panel (b) shows an $m / z$ with an isotopologue $\left(\mathrm{Na}_{2}^{37} \mathrm{Cl}^{+}\right)$, together with a hydrocarbon-like organic fragment $\left(\mathrm{C}_{6} \mathrm{H}_{11}^{+}\right)$. Panel (c) shows a dominant oxygenated ion $\left(\mathrm{CH}_{2} \mathrm{O}^{+}\right)$. Note that the $\mathrm{NO}^{+}$ion is not accounted for in the PMF analysis, as it is not part of the input matrix, but appears in the HR analysis of the whole spectrum. Panels (d) and (e) indicate the presence of aliphatic organics and also sulphur-containing fragments such as $\mathrm{CHS}^{+}$. Based on the available data, it is not possible to state whether the sea salt and the organic components are internally or externally mixed. Linear regression between the $\mathrm{Na}^{35} \mathrm{Cl}^{+}$and $\mathrm{CHS}^{+}$, $\mathrm{C}_{2} \mathrm{H}_{3} \mathrm{O}^{+}$and $\mathrm{C}_{3} \mathrm{H}_{7}^{+}$ion fragments resulted in low correlation coefficients of $R^{2}=0.21, R^{2}=0.03$ and $R^{2}<0.01$, respectively. This suggests that the aerosol is more likely to be externally mixed, which is in agreement with findings by Gaston et al. (2011), who report on two aerosol subpopulations within sea spray aerosol. Comparable measurements by Ceburnis et al. (2011) however suggest that this type of aerosol might be internally mixed. Based on a recent review (Gantt and Meskhidze, 2013) it is thought that particles with smaller diameter $(d<200 \mathrm{~nm})$ are more likely to be externally mixed, while larger particles $(d>1000 \mathrm{~nm})$ are more likely to be internally mixed. The sea spray organic aerosol factor observed here is associated with two submicron volume size distribution modes with diameters of $300 \pm 120$ and $560 \pm 20 \mathrm{~nm}$ and one additional mode in the super-micron size range, at $3.01 \pm 0.03 \mu \mathrm{m}$ (see Fig. 6).

The PMF sea spray factor is highly correlated with particulate chloride $\left(R^{2}=0.64\right)$ and potassium $\left(R^{2}=0.61\right)$. All three aerosol species are similarly dependent on wind speed, as shown in Fig. 11. This is indication for a common source. Below wind speeds of $8 \mathrm{~m} \mathrm{~s}^{-1}$ (measured at $10 \mathrm{~m}$ above ground), concentrations are almost invariably low in all three cases. Between 8 and $10 \mathrm{~m} \mathrm{~s}^{-1}$ concentrations increase slightly, and at wind speeds greater than $10 \mathrm{~m} \mathrm{~s}^{-1}$ they increase roughly by a factor of three. Comparable observations have been made by Ovadnevaite et al. (2012). Because vertical dilution is also enhanced at high wind speed, the dependence of the source function on wind speed is stronger than reflected in these concentration measurements. The fractions of potassium originating from sea salt and other sources are discussed separately in Sect. 3.10.3. 
Table 7. Ten most dominant fragments of the $\mathrm{C}_{x} \mathrm{H}_{y} \mathrm{~N}_{z}$ series of the amino acid/amine factor, ordered according to their mass contribution in percent.

\begin{tabular}{llll}
\hline$m / z$ & Exact mass & Formula & Contribution $(\%)$ \\
\hline 42 & 42.03 & $\mathrm{C}_{2} \mathrm{H}_{4} \mathrm{~N}^{+}$ & 25 \\
55 & 55.04 & $\mathrm{C}_{3} \mathrm{H}_{5} \mathrm{~N}^{+}$ & 11 \\
57 & 57.06 & $\mathrm{C}_{3} \mathrm{H}_{7} \mathrm{~N}^{+}$ & 8 \\
56 & 56.05 & $\mathrm{C}_{3} \mathrm{H}_{6} \mathrm{~N}^{+}$ & 7 \\
112 & $112.10,112.11$ & $\mathrm{C}_{6} \mathrm{H}_{12} \mathrm{~N}_{2}^{+}, \mathrm{C}_{7} \mathrm{H}_{14} \mathrm{~N}^{+}$ & 6 \\
80 & 80.04 & $\mathrm{C}_{4} \mathrm{H}_{4} \mathrm{~N}_{2}^{+}$ & 5 \\
58 & 58.06 & $\mathrm{C}_{3} \mathrm{H}_{8} \mathrm{~N}^{+}$ & 5 \\
41 & 41.06 & $\mathrm{C}_{2} \mathrm{H}_{3} \mathrm{~N}^{+}$ & 5 \\
53 & 53.03 & $\mathrm{C}_{3} \mathrm{H}_{3} \mathrm{~N}^{+}$ & 3 \\
30 & 30.03 & $\mathrm{CH}_{4} \mathrm{~N}^{+}$ & 3 \\
\hline
\end{tabular}

Figure 13 shows the correlation between the total number concentration of large particles measured by the APS $(0.54$ to $20 \mu \mathrm{m})$ and the sea spray factor. Two branches are visible that are clearly distinguished by the concentration of the amino acid/amine PMF factor (colour code). The AA concentration is smaller than $0.01 \mu \mathrm{g} \mathrm{m}^{-3}$ in the "high sea spray branch", while it is larger than $0.01 \mu \mathrm{g} \mathrm{m}^{-3}$ in the "low sea spray branch". Both branches have a correlation coefficient of $R^{2}=0.61$. While it is expected that sea spray correlates with the super-micron particle fraction, the behaviour of the amino acid/amine factor is described in detail in the next section.

\subsection{Amino acids and amines}

The amino acid and amine (AA) factor's time series is unique (see Fig. 5b) because it differs strongly from time series of all other measured parameters. It was observed from 3 until 21 November, with a break between 12 and 15 November, and on 4 and 5 December. The maximum recorded concentration was $0.17 \mu \mathrm{g} \mathrm{m}^{-3}$ on 12 November. During the peak periods, the average mass concentration was $0.05 \pm 0.04$, while for background conditions it was $0.002 \pm 0.002 \mu \mathrm{g} \mathrm{m}^{-3}$.

Chemically, the AA factor was characterised by a series of nitrogen-containing ion fragments $\left(\mathrm{C}_{x} \mathrm{H}_{y} \mathrm{~N}_{z}\right)$ that include contributions at 44 different mass-to-charge ratios. In Fig. 12 the five most dominant nitrogen-containing ion fragments are presented. In Table 7 the 10 most dominant fragments are listed, which make up $78 \%$ of the $\mathrm{C}_{x} \mathrm{H}_{y} \mathrm{~N}_{z}$ series, together with their chemical formulae and exact mass, ordered by their relative contribution. While this series contributed about $22 \%$ to the OA species, fragments that contained both nitrogen and oxygen $\left(\mathrm{C}_{x} \mathrm{H}_{y} \mathrm{O}_{z} \mathrm{~N}\right)$ contributed only $1 \%$. Overall, singly oxygenated compounds (i.e. $\mathrm{C}_{x} \mathrm{H}_{y} \mathrm{O}$ ) made up $6 \%$, while multiply oxygenated compounds $\left(\mathrm{C}_{x} \mathrm{H}_{y} \mathrm{O}_{z}\right.$; $z>1$ ) contributed $40 \%$, with the $\mathrm{CO}_{2}^{+}$fragment accounting for most of this series. Aliphatic fragments $\mathrm{C}_{x} \mathrm{H}_{y}$ contributed $28 \%$, while $\mathrm{C}_{x}$ corresponded to $3 \%$ of the mass (see Fig. 14a). To test whether the nitrogen-containing ion sig-

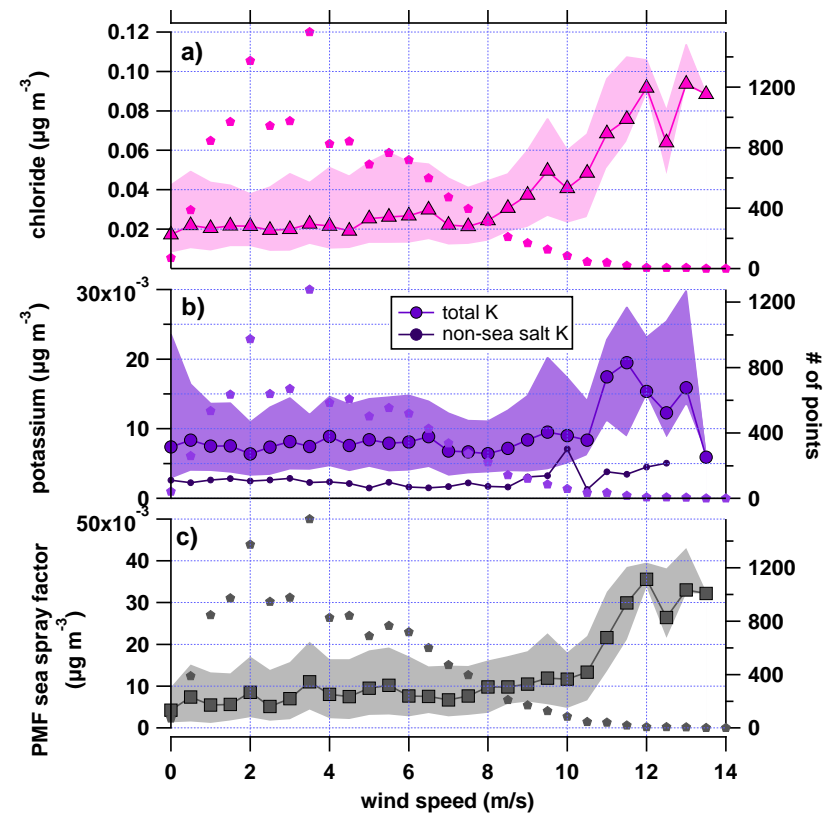

Fig. 11. PMF sea spray factor, particulate potassium (total and nonsea salt) and chloride versus wind speed at $10 \mathrm{~m}$ above ground in bins of $0.25 \mathrm{~m} \mathrm{~s}^{-1}$. The markers indicate the median value while the shaded areas represent the inter-quartiles. The pentagons indicate the number of samples per bin.

nals can reliably be isolated from neighbouring ions the linear correlation between $\mathrm{C}_{2} \mathrm{H}_{4} \mathrm{~N}$ and $\mathrm{C}_{3} \mathrm{H}_{6}\left(m / z\right.$ 42), $\mathrm{C}_{3} \mathrm{H}_{5} \mathrm{~N}$ and $\mathrm{C}_{4} \mathrm{H}_{7}\left(m / z\right.$ 55), $\mathrm{C}_{3} \mathrm{H}_{7} \mathrm{~N}$ and $\mathrm{C}_{4} \mathrm{H}_{9}\left(m / z\right.$ 57), and $\mathrm{C}_{3} \mathrm{H}_{6} \mathrm{~N}$ and $\mathrm{C}_{4} \mathrm{H}_{8}(m / z, 56)$ were tested. All $R^{2}$ are smaller than 0.2.

The AA factor did not appear to be correlated with any other chemical species measured by the AMS, nor with the basic meteorological parameters, and all absolute values of the derived correlation coefficients are smaller than $R^{2}=$ 0.08. This analysis is consistent with the factor's time series optically being very different from all other time series (see Fig. 2a-d, Fig. 3b and Fig. 5b). Such an episodically characterised time series of amine-containing aerosol has been reported previously (Sun et al., 2012); it is however poorly explained. This leads to the question regarding the source of this OA type. Chemically, it has been shown that this factor contained amino acid and amine signatures (Hildebrandt et al., 2011; Schneider et al., 2011). Previous studies reported that protein signatures, free amino acids and amines were observed in the aerosol of the remote marine atmosphere (Aller et al., 2005; Kuznetsova et al., 2005; Facchini et al., 2008a; Müller et al., 2009; Dall'Osto et al., 2012; Scalabrin et al., 2012). However, so far studies have indicated that the amine and amino acid sources were either related to secondary biologically driven marine aerosol formation related to MSA signatures (Facchini et al., 2008a; Müller et al., 2009) or primary aerosol production during bubble bursting (Kuznetsova et al., 2005). Both sources can most likely be excluded in this case, as no correlation with the MSA-OA factor nor with 

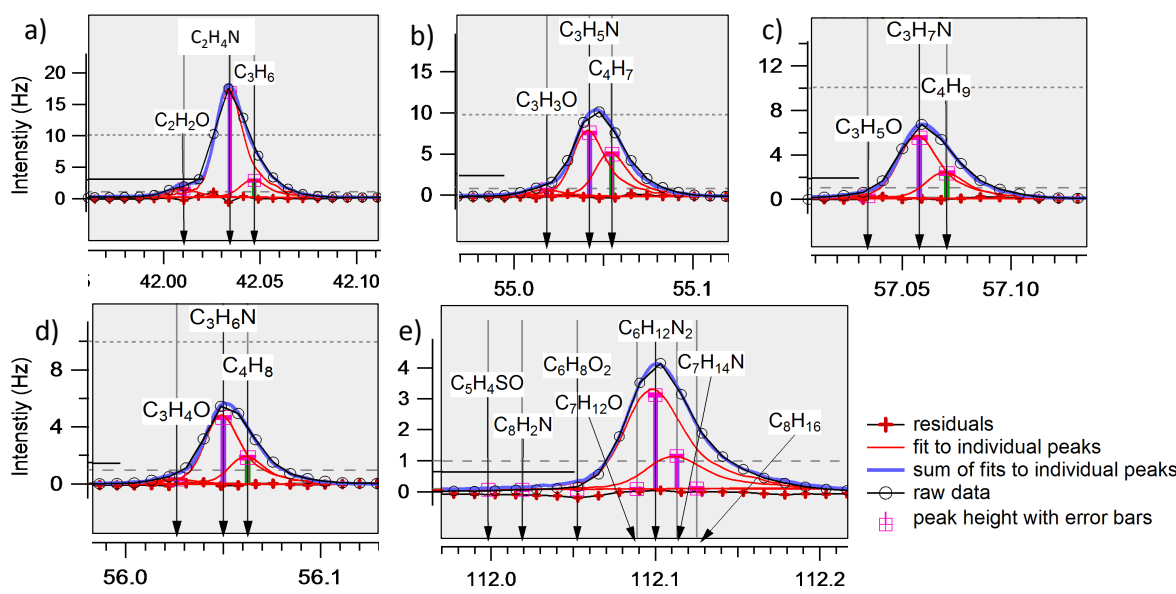

Fig. 12. Selection of high-resolution marker ion fragments for the AA-OA PMF factor in the difference spectrum.

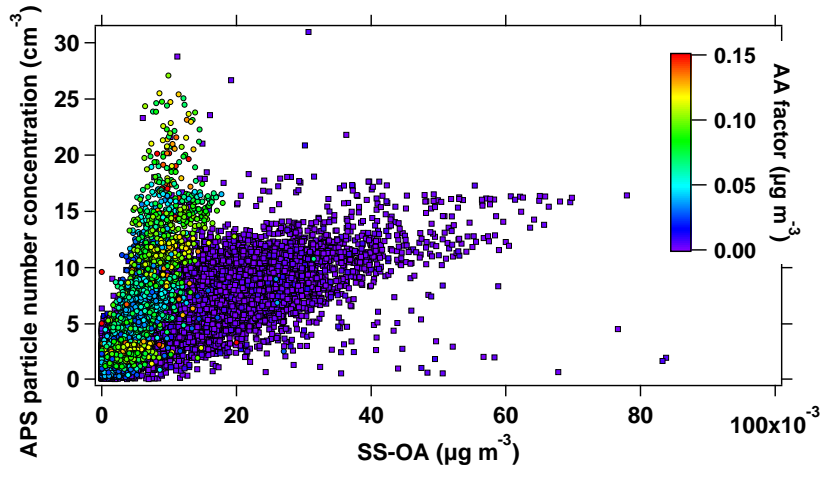

Fig. 13. APS total number concentration versus the PMF factor sea spray concentration; colour code refers to the concentration of the amino acid/amine PMF factor.

sea spray were observed. Also, sources such as fires or volcanic eruptions, as identified by Scalabrin et al. (2012), can be ruled out.

Linear regressions with the individual amino acids, as selected in Schneider et al. (2011), also measured by an AMS, yielded a significant correlation with valine $\left(R^{2}=0.55\right)$. Glutamic acid $\left(R^{2}=0.22\right)$, alanine $\left(R^{2}=0.18\right)$, leucine $\left(R^{2}=0.16\right)$ and proline $\left(R^{2}=0.16\right)$ were the next most correlated amino acids. The marker ions at $m / z 112$ have not been reported before, but were most likely an indicator for the amino acid arginine based on a comparison to the mass spectrum of arginine from the Japanese spectral database for organic compounds (http://riodb01.ibase.aist.go.jp), where $\mathrm{m} / z, 112$ contributed $2 \%$ of the mass. The high contribution of amino acids to this factor suggests that the source was of biological nature. Wedyan and Preson (2008) reported that glycine and alanine were the most dominant amino acids contained in remote Atlantic Ocean aerosol, originating from the sea-surface micro layer (SSML). Correlation of the AA factor with the glycine laboratory spectrum from Schneider
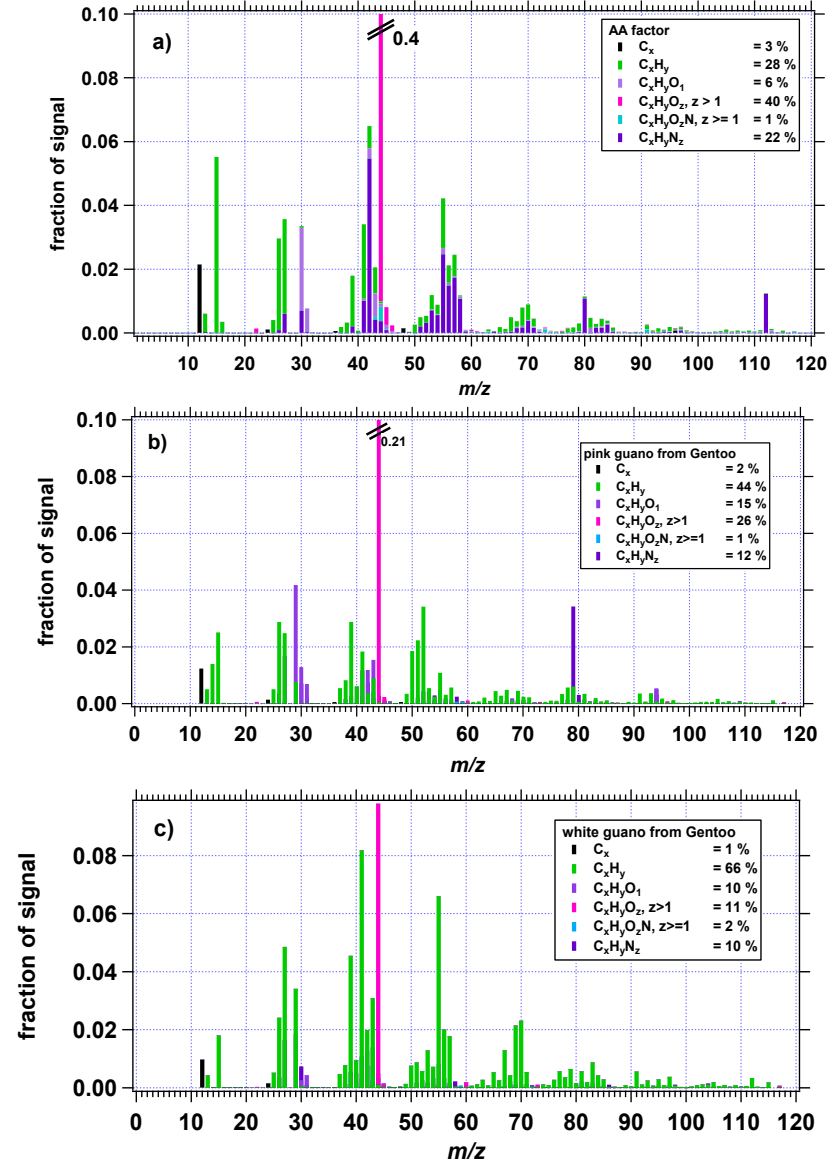

Fig. 14. Speciated organic mass spectrum of the amino acid/amine PMF factor (a), pink guano from gentoo (b) and white guano from gentoo (c). The percentages in the legend indicate the mass contribution to the total organic matter spectrum. 


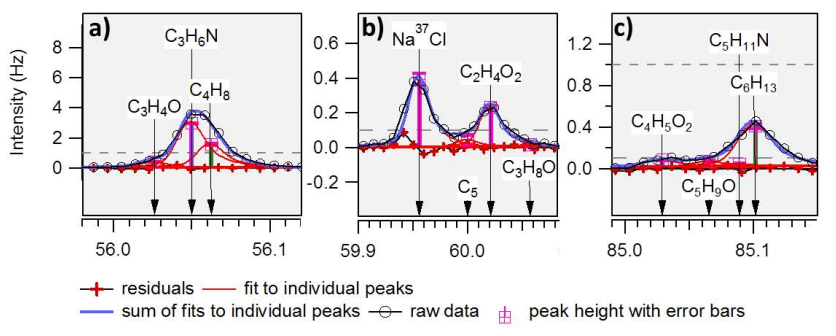

Fig. 15. Selected $m / z$ where carbohydrate ion fragments are expected.

et al. (2011) could not be observed $\left(R^{2}<0.01\right)$. This suggests that SSML is unlikely to have been the major source of the AA factor or that SSML constituents are significantly different around Bird Island.

Laboratory AMS measurements of pure carbohydrates (Schneider et al., 2011) showed the following typical fragments: $m / z 56\left(\mathrm{C}_{3} \mathrm{H}_{4} \mathrm{O}^{+}, 56.03\right), m / z 60\left(\mathrm{C}_{2} \mathrm{H}_{4} \mathrm{O}_{2}^{+}, 60.02\right)$, $m / z 61\left(\mathrm{C}_{2} \mathrm{H}_{5} \mathrm{O}_{2}^{+}, 61.03\right), m / z 73\left(\mathrm{C}_{3} \mathrm{H}_{5} \mathrm{O}^{+}, 73.03\right)$, and $m / z 85\left(\mathrm{C}_{4} \mathrm{H}_{5} \mathrm{O}_{2}^{+}, 85.03\right)$. Figure 15 provides examples for $m / z 56,60$ and 85 from Bird Island data, showing that the intensity of the carbohydrate fragments was very low. Other fragments such as $\mathrm{C}_{3} \mathrm{H}_{6} \mathrm{~N}^{+}$(Fig. 15a), $\mathrm{Na}^{37} \mathrm{Cl}^{+}$(b) or $\mathrm{C}_{6} \mathrm{H}_{13}^{+}$(c) dominated the mass at these specific mass-tocharge ratios. Overall, the five mentioned carbohydrate fragments made up only about $0.1 \%$ of the AA aerosol mass. This leads to the conclusion that these particles most likely did not originate from typical bacterial cell fragments, which contain about $55 \%$ proteins and amino acids and $10 \%$ carbohydrates (Watson et al., 2007).

This observation, together with the lack of correlation with other time series associated with marine emissions such as MSA-OA or sea spray, suggests that the ocean was not the source of this biological aerosol particle (BAP) type, even though bacteria and viruses emitted through bubble bursting processes in the sea-surface micro layer are known to be enriched in the aerosol phase (Aller et al., 2005). A potential source for the observed BAP not associated with oceanic emissions was the local fauna on Bird Island. During the measurement period penguins, other seabirds and fur seals populated the island in large numbers. In the immediate vicinity of the station, more than 3500 fur seals and 1000 penguins were present in early December. In November, when the AA factor was primarily observed, fur seals were just beginning to arrive at the island. Their peak pupping time is during December, so it can most likely be concluded that they were not contributing substantially to the AA particle source. Penguins, however, had already built their nests on the island when measurements started. The only recorded fauna-related activity that coincided with the AA factor observations was the hatching period of Pygoscelis рариа (gentoo penguins) at the Square Pond and Landing Beach colonies (see Fig. 1, green and blue stars). At Square

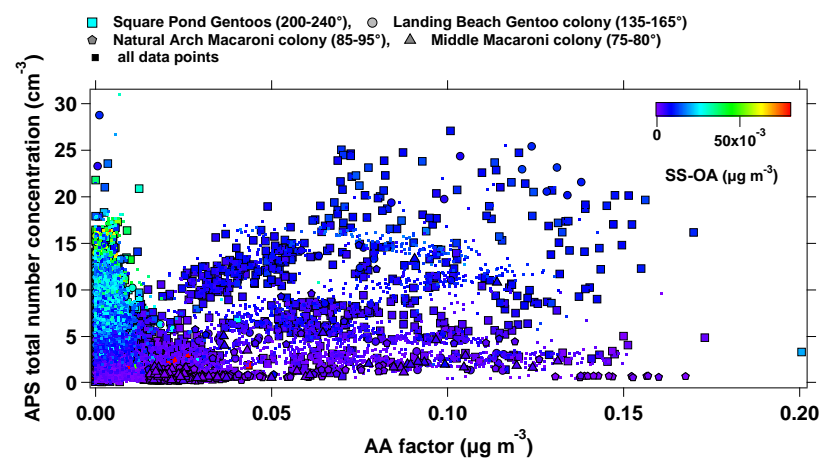

Fig. 16. Total number concentration of aerosol particles between 0.54 and $19.81 \mu \mathrm{m}$ versus the amino acid/amine factor. The large square markers indicate data points related to the Square Pond gentoo penguin colony, the large circles relate to data points from the Landing Beach colony, the pentagons refer to the Natural Arch macaroni colony, the triangles to the Middle macaronic colony, and the small squares represent all data points. The colour code indicates the mass concentration of the PMF sea spray factor.

Pond 460 nests were built and about 530 eggs laid, starting from 3 October, with more than $75 \%$ of the eggs laid by 10 October. Chicks started hatching after 35 days on average, which coincides with the AA factor observation period. At Landing Beach, the first egg was seen on 28 September and the first chick hatched on 9 November. The number of nests counted was 116, but there was no record of individual eggs. Based on the local wind direction measurements, increased AA concentrations could be related to the Square Pond (200-240 ${ }^{\circ}, \mathrm{SW}, 800 \mathrm{~m}$ distance to station) and the Landing Beach (135-165 ${ }^{\circ}$, SE, $400 \mathrm{~m}$ to station) colonies. Observations from the literature report that primary BAP concentrations associated with larger particle sizes (Huffman et al., 2010; Pöschl et al., 2010). Figure 16 provides a strong indication that the AA factor was related to the hatching period at the two colonies. The figure shows a scatter plot of total aerosol number density measured by the APS versus the AA factor mass concentration. As already shown in Fig. 13, AA particles were correlated with the super-micron fraction of aerosol particles. To prevent the large particles from being associated with sea spray aerosol, all data points are colourcoded by the PMF-derived sea spray factor. Data points related to gentoo colonies at Square Pond and Landing Beach, and macaroni colonies at Natural Arch and Middle Mac are indicated by the larger symbols (square, circle, pentagon, triangle, respectively; see Fig. 1 for locations). The concentration of the AA factor is typically below $0.015 \mu \mathrm{g} \mathrm{m}^{-3}$ during periods of elevated sea spray concentration. Above this threshold the sea spray influence diminishes. A significant number of these non-sea-spray super-micron particles seem to have originated from the directions of the abovelisted colonies, while the relative contribution of these directions to the occurrences of large sea spray coarse aerosol concentrations was much smaller. Summing up all particles 
measured by the APS, when sea spray was not the dominant species in the super-micron fraction (i.e. sea spray concentration $<0.02 \mu \mathrm{g} \mathrm{m}^{-3}$, and AA factor $>0.015 \mu \mathrm{g} \mathrm{m}^{-3}$ ), the fraction of the Square Pond penguin particles is $12 \%$, the largest contribution among all considered colonies. Accounting only for APS-measured particles coming from this colony's wind direction $\left(200-240^{\circ}\right)$ the AA particles made up $35 \%$ for the measurement period from November through December. For Landing Beach, AA particles account for $24 \%$ of particles, while at Middle Mac it is $19 \%$. The contribution of AA particles from the Natural Arch colony is $38 \%$. However, the amino acid/amine concentrations coming from Square Pond and Landing Beach are much higher (see Fig. 16).

The actual AA particle (super-micron aerosol) or precursor (submicron aerosol) emission process during hatching could only be inferred based on available data and by excluding other potential sources. It seems plausible that a compound rich in proteins was released during egg laying and hatching. In addition to the egg albumen, the cuticle of the egg and the inner and outer membranes consist of 85-87\%, $88-92 \%$ and $93-96 \%$ proteins, respectively, containing the amino acids glutamic acid, leucine, valine, proline and arginine among others (Wedral et al., 1974). It is conceivable that either primary particles were generated during egg laying and/or hatching or that condensed evaporated compounds from the wet hatched chicks led to amino acid signatures in ambient aerosol. Potentially, feather fragments could also have been responsible for the observations, as they have a similar chemical composition to the egg membranes or the albumen (Murphy et al., 1990). However, no elevated AA concentrations were observed during periods (several hours) when large numbers of scavenger birds fought over fur seal carcasses in close proximity to the research station's laboratory with the aerosol inlet. The association of the factor with larger-sized particles suggests that some of the particles may have been of primary nature. However, the partially high concentrations in the submicron aerosol suggest that the particle type was of secondary origin. Free amino acids have been found to be enriched in the accumulation mode particles in Arctic aerosol (e.g. Scalabrin et al., 2012). In addition, animal husbandries are known sources of amines (Ge et al., 2011). It was also observed that the occurrence of the amino acid/amine concentration was not related to wind speed.

Particle generation from bird guano could also have been the source of the AA particles. It is known that ornithogenic soils emit significant quantities of ammonia, have a high $\mathrm{N}: \mathrm{C}$ ratio (0.1, Beyer et al., 1997), and are characterised by a high percentage of amino derivates from proteins, polysaccharides, urates, chitin, oxalates and nitrate, all components of penguin guano (Beyer et al., 1997; Legrand et al., 2012). On Bird Island two different guano samples from gentoo penguins, white (no krill in the diet) and pink (with krill), were collected, dissolved in distilled water and nebulised, and the resulting aerosol dried and sampled with the AMS; see Fig. 14b, c. HR PIKA analysis revealed that the white guano mass spectrum had almost no similarities with the AA mass spectrum, but it contained traces of carbohydrates $\left(m / z 60.02, \mathrm{C}_{2} \mathrm{H}_{4} \mathrm{O}_{2}^{+} ; m / z 73.03, \mathrm{C}_{3} \mathrm{H}_{5} \mathrm{O}^{+}\right.$; and $m / z$ 85.03, $\left.\mathrm{C}_{4} \mathrm{H}_{5} \mathrm{O}_{2}^{+}\right)$, oxalates $\left(m / z 45.00, \mathrm{COOH}^{+}\right.$and $m / z$ 46.00, $\left.\mathrm{CH}_{2} \mathrm{O}_{2}^{+}\right)$, uric acid $\left(m / z\right.$ 43.00, $\mathrm{CHNO}^{+} ; m / z$ 125.02, $\mathrm{C}_{4} \mathrm{H}_{3} \mathrm{~N}_{3} \mathrm{O}_{2}^{+} ; m / z$ 54.03, $\mathrm{C}_{3} \mathrm{H}_{4} \mathrm{~N}^{+}$; and $m / z 69.06, \mathrm{C}_{4} \mathrm{H}_{7} \mathrm{~N}^{+}$) and other acids. The pink guano spectrum displayed the same ion fragments and in addition a large number of nitrogencontaining compounds that resembled the series of $\mathrm{C}_{x} \mathrm{H}_{y} \mathrm{~N}_{z}$ observed in the AA spectrum that made up $12 \%$ of the organic guano matter. $\mathrm{C}_{x} \mathrm{H}_{y} \mathrm{O}_{z} \mathrm{~N}$ contributed $1 \%$. Simply oxygenated compounds $\left(\mathrm{C}_{x} \mathrm{H}_{y} \mathrm{O}\right)$ made up $14 \%$ (9\% more than the AA factor), while $\mathrm{C}_{x} \mathrm{H}_{y} \mathrm{O}_{z}(z>1)$ contributed $26 \%$, mostly via the $\mathrm{CO}_{2}^{+}$fragment. Aliphatic fragments $\mathrm{C}_{x} \mathrm{H}_{y}$ contributed $44 \%$, while $\mathrm{C}_{x}$ accounted for $2 \%$. However, given that there were no significant traces for uric acid, oxalates or carbohydrates in the AA factor, it is unlikely that the wind-driven generation of guano aerosol was responsible for the AA factor signal. The numbers of gentoo penguin chicks hatching is small, but at present these appear to be the most likely source of amino-acid-/amine-rich particles; further research is needed to confirm this.

\subsection{Marine oxygenated organic aerosol}

Marine oxygenated organic aerosol (M-OOA) contributed on average $41 \%$ to the organic aerosol mass and was continuously present, in contrast to all other PMF-derived OA species. Therefore it can be characterised as a background aerosol type whose source was most likely the ocean, as no other plausible source could be identified. Together with MSA-OA and the sea spray organics factors, it was the third $\mathrm{OA}$ species of marine origin identified by the PMF analysis. By contrast to MSA-OA, M-OOA was mainly associated with a north-westerly wind direction (see Fig. 17b) and the back trajectory clusters West, Ocean, and South America (see Fig. 7). Figure 17a shows the HR analysisderived mass spectrum from the time interval indicated in Fig. 5b. The main contributions were associated with oxygenated compounds $\left(61 \%\right.$ from $\mathrm{C}_{x} \mathrm{H}_{y} \mathrm{O}$ and $\left.\mathrm{C}_{x} \mathrm{H}_{y} \mathrm{O}_{z}\right)$ and aliphatic compounds $\left(30 \% \mathrm{C}_{x} \mathrm{H}_{y}\right)$. Nitrogen-containing ion fragments made up around $4 \%$. Ovadnevaite et al. (2011) and Crippa et al. (2013) reported a comparable marine organic aerosol signature, where oxygenated compounds accounted for $63 \%$ and $64 \%$ and hydrocarbon-like compounds for $37 \%$ and $33 \%$ of the mass, respectively. The linear regression correlation coefficient between the PMF Bird Island M-OOA and Mace Head (Ireland) marine OA was $R^{2}=0.71$ (not accounting for $m / z$ 28, 29, 43 and 44, which had significantly higher mass contributions and would have artificially increased the correlation to $R^{2}=0.88$ ). The correlation with the Crippa et al. (2013) spectrum is $R^{2}=0.47$. In addition, the M-OOA spectrum appears to be similar to the marine oxygenated organic aerosol PMF factor observed by Chang et al. (2011) in the Arctic Ocean which has a 


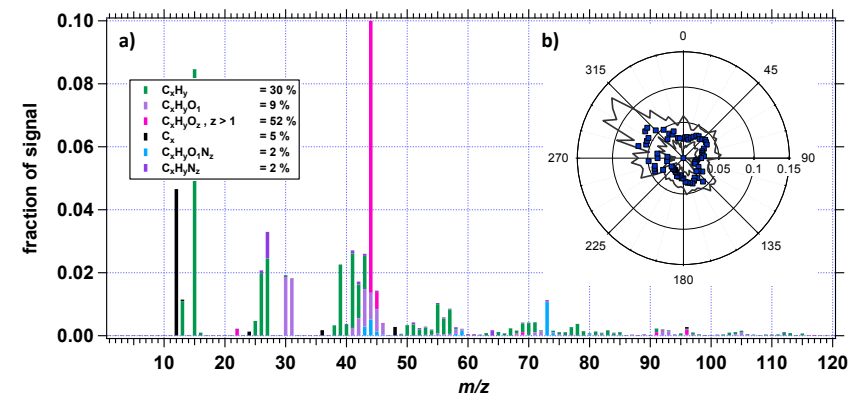

Fig. 17. (a) Speciated organic mass spectrum of M-OOA and (b) wind rose of M-OOA mass concentrations in $\mu \mathrm{g} \mathrm{m}^{-3}$. The blue markers indicate the median concentration while the black lines denote the 25 th and 75 th percentiles.

correlation coefficient of $R^{2}=0.81$ with the spectrum from Ovadnevaite et al. (2011) and an $R^{2}$ of 0.63 with the Bird Island M-OOA factor $\left(R^{2}\right.$ would be 0.89 when including $m / z 28,29,43$ and 44 in the regression). Based on the unit mass resolution spectrum the contribution of $m / z 44$ to the organic mass spectrum $\left(f_{44}\right)$ is $17 \%$ for the Arctic MOOA, while our M-OOA factor shows an $f_{44}$ of $22 \%$. Ovadnevaite et al. (2011) concluded that their observed plume was most likely of primary origin, mainly due to relatively high wind speed, increased sea spray mass concentrations

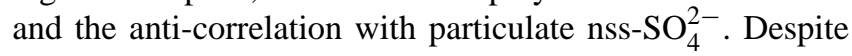
the similarity in the organic mass spectrum, however, the Bird Island M-OOA is anti-correlated with local wind speed $\left(R^{2}=0.04\right)$ and has very little correlation with particulate chloride $\left(R^{2}=0.02\right)$, whose dominant source is sea salt. Also, no significant correlation with super-micron particles was found $\left(R^{2}=0.01\right)$. However, based on these observations, a primary source of M-OOA linked to sea spray aerosol production could not be ruled out, as the sea salt and organic aerosol particles could have been externally mixed (Gantt and Meskhidze, 2013, and references therein). Subsequently, fresh marine organic aerosol, likely to have a low water solubility (Hawkins and Russell, 2010), may have undergone chemical ageing during atmospheric transport, leading potentially to a decoupling between water soluble, most likely local sea spray signals and M-OOA observations. Decesari et al. (2011) suggested that primary marine organic matter can be processed into OM resembling secondary OA, making the two aerosol types hardly discernible. Also, sea spray aerosol organic matter has been found to decrease with increasing wind speeds (e.g. Gantt et al., 2011), a factor that may have introduced high variability into the correlation between organic matter and sea salt particles.

\subsection{Sources and distribution of selected elements and compounds in the particulate phase}

In this section we discuss the contribution of chemical elements to the Bird Island organic and inorganic aerosol, with the emphasis on nitrogen and potassium and potential sources of sulphur.

\subsubsection{O : $\mathrm{C}, \mathrm{N}: \mathrm{C}$ and $\mathrm{H}: \mathrm{C}$ ratios}

Elemental ratios can add more specific information regarding chemical characteristics of the aerosol than revealed by the UMR-based PMF solution. Figure 18 shows the elemental ratios of oxygen, hydrogen and nitrogen to carbon for each of the PMF-derived organic aerosol species. M-OOA was the most oxygenated species, with an $\mathrm{O}: \mathrm{C}$ ratio of 1.05 . The red cross denotes the $\mathrm{O}: \mathrm{C}$ ratio, as reported by Ovadnevaite et al. (2011), which was lower at 0.6 , while the white circle represents measurements by Crippa et al. (2013) with 0.57. The HOA factor exhibited a rather high $\mathrm{O}: \mathrm{C}$ ratio of $0.38 \mathrm{com}-$ pared with previous studies (Ng et al., 2010, and references therein). Sea spray organics had the second highest oxygen content, with an $\mathrm{O}: \mathrm{C}$ ratio of $0.51 . \mathrm{H}: \mathrm{C}$ ratios were similar for most OA species, with MSA-OA having the highest ratio of 2.20. Again, the $\mathrm{H}: \mathrm{C}$ ratio of M-OOA exceeded the ratio of the Mace Head plume (1.61 versus 1.25). The amino acid/amine factor exhibited the highest $\mathrm{N}: \mathrm{C}$ ratio of 0.13 , followed by MSA-OA with 0.08 .

\subsubsection{Nitrogen}

Nitrogen was contained in several different compounds in Bird Island aerosol. Inorganic species included nitrate and ammonium, while for the organic species nitrogen was predominantly contained in the AA and MSA-OA factors (see Fig. 18). Figure 19 shows the correlation between organic aerosol nitrogen (OA-N) and approximated inorganic nitrogen on Bird Island. The OA-N was calculated by multiplying the organic mass of each PMF-derived species by the quotient of its ratios of $\mathrm{N}: \mathrm{C}$ and $\mathrm{OM}: \mathrm{C}$. The inorganic nitrogen was approximated stoichiometrically from particulate nitrate and ammonium. We refer to this as approximated inorganic nitrogen, as parts of the nitrate and ammonium signal may have been of organic origin. Two branches were observed that were associated with the amino acid/amine factor and with MSA-OA, respectively. In the more vertically orientated branch, where inorganic nitrogen varied mainly between 0.00 and $0.06 \mu \mathrm{g} \mathrm{m}^{-3}$, the organic nitrogen reached a maximum because of high AA factor concentrations. In the other branch, there was a linear relationship $\left(R^{2}=0.53\right.$, slope $=0.03$ ) between the increase of organic and inorganic nitrogen when MSA-OA became more dominant. The reason for the latter correlation was the co-formation of sulfur dioxide from DMS oxidation and subsequent formation of sulfuric acid, which pulled higher ammonium concentrations into the aerosol. This process was only possible due to the high availability of ammonia from the Bird Island local fauna. It was also observed that the molar ratio of particulate ammonium to sulfate increased from $1.16 \pm 0.35$ in November to $1.50 \pm 0.45$ in December. Similar trends have been observed 


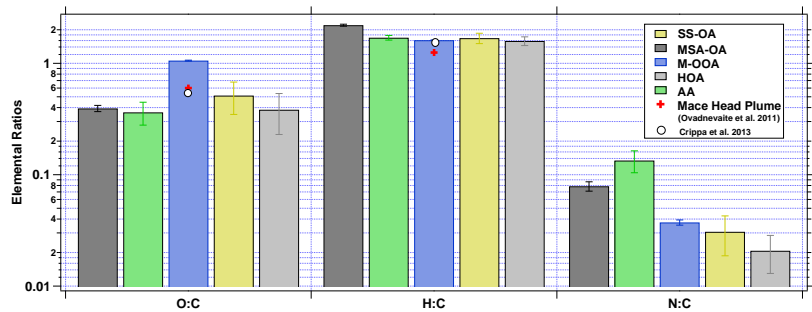

Fig. 18. Elemental ratios for each PMF-derived OA species based on HR PIKA analysis on the time interval as indicated in Fig. 5b.

previously in Antarctica, with ratios of 1.05 and 1.35, respectively, by Johnson and Bell (2008) in their study on coupling DMS emissions with ocean-atmosphere ammonia exchange.

\subsubsection{Potassium}

As shown in Fig. 11, potassium was associated with the sea salt aerosol, as its concentration was a function of wind speed, similar to chloride and the PMF sea spray factor. Note that high wind speeds might also enhance emissions of potassium from ornithogenic soils. Observations however indicate that sea salt was not the only source of potassium. To estimate the contribution of non-sea-salt potassium (nss- $\mathrm{K}^{+}$) sources, the ratio of potassium to chloride was determined for all data associated with a wind direction between 300 and $315^{\circ}$, as both $\mathrm{K}^{+}$and chloride arrived predominantly with north-westerly winds which coincided with their highest concentrations. The 90th percentile of this ratio was used as a threshold to distinguish between nss- $\mathrm{K}^{+}($ratio $\geq 0.71)$ and sea salt potassium for all available data. Nineteen (19) \% of the data points exceed this threshold. This potassium could be of biogenic origin. High enrichment of potassium with respect to sea salt in aerosol has been found during the summer months in Antarctica in the vicinity of a penguin colony, originating from penguin nasal excreta (Legrand et al., 1998). However, the link between the potential source and potassium-containing particles is not well understood.

\subsubsection{Sulfate}

Particulate sulfate had three potential sources on Bird Island. Firstly, about $10.7 \%$ (median value) of the observed sulfate originated from sea salt, as discussed in Sect. 3.1.1. Secondly, particulate sulfate was associated with DMS oxidation, as the high correlation $\left(R^{2}=0.69\right)$ between the PMFderived MSA-OA factor and particulate sulfate suggests. And thirdly, sulfate was potentially advected through longrange transport from the South American continent. Even though the correlation between M-OOA, whose trajectories have passed over the North American continent, and particulate sulfate $\left(R^{2}=0.01\right)$ was low, there were certain periods when both particulate sulfate and M-OOA were elevated and MSA-OA and sea salt mass concentrations, the other po-

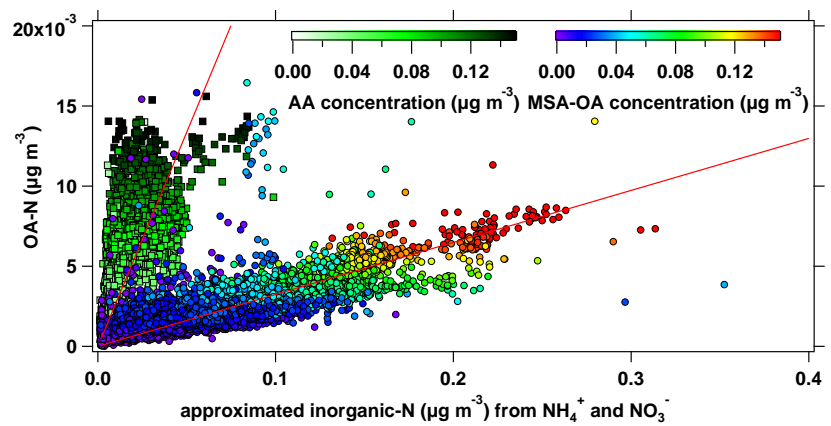

Fig. 19. Correlation between organic and approximated inorganic nitrogen on Bird Island. The green and rainbow colour codes represent the mass concentrations of the amino acid/amine and MSA-OA factors, respectively. Circles indicate that the MSA-OA factor was dominant over the AA factor (12-15 November, 21 November-4 December, and 5-29 December), while squares indicate the inverse situation (compare Fig. 5). The red lines represent the linear regression fits to both branches (slope $=0.03 \pm 0.00, R^{2}=0.53$ for the MSA-OA dominant branch, and slope $=0.27 \pm 0.00, R^{2}=0.43$ for the AA-OA dominant branch).

tential sources for sulfate, were low (see Fig. 9 red ellipse). The correlation between M-OOA and the low volatile-OOA (LV-OOA) mass spectrum after $\mathrm{Ng}$ et al. (2011), representing aged anthropogenic OA, was moderate with $R^{2}=0.40$ (A_DEC_Q_017 in the AMS UMR mass spectrum reference database). Therefore significant anthropogenic influences on the background aerosol on remote Bird Island could be ruled out.

\section{Conclusions}

This study reports the first stationary deployment of an aerosol mass spectrometer (AMS) to a field site in the subAntarctic and presents a detailed characterisation of the particulate composition and size distribution for eight weeks during the Antarctic summer, from November to December 2010. Sub- and super-micron particle measurements were conducted on Bird Island in the South Atlantic Ocean to determine the influence of biogenic sources, such as seabirds and marine mammals, on the characteristics of aerosol particles.

$\mathrm{PM}_{1}$ was composed of $21 \%$ nss-sulfate, $2 \%$ nitrate, $8 \%$ ammonium, $22 \%$ organics and $47 \%$ sea salt including sssulfate. The observed aerosol was more neutralised than found in other comparable studies, which is explained by the high availability of ammonia emitted by the fur seal and bird colonies. Three distinct sources of particulate sulfate could be determined on the remote island: sea salt sulfate, sulfate from DMS oxidation and long-range transported particles from South America. For potassium it was found that about $19 \%$ of the mass was not of sea salt origin, most likely indicating the presence of biological aerosol particles. 
In addition to the strong influence of biogenic ammonia emissions on the chemical composition of the submicron aerosol, specific organic compounds could also be linked to biologically driven emissions. We attributed $18 \%$ of the organic mass fraction to a positive matrix factorisation profile dominated by fragments of amino acids and amine (AA factor). The occurrence of this factor was most likely associated with the hatching of gentoo penguins at two nearby colonies (Square Pond and Landing Beach) during the first half of November, as the signal was almost exclusively observed during that period and influence from other seabirds and fur seals could be excluded due to their breeding chronology. Further work is needed to confirm the assumption that egg or feather components or volatiles emitted during hatching were responsible for the signal. It may be possible to carry out an experiment with chicken eggs as proxies, as the composition of penguin eggs and feathers is comparable to those of chicken (Williams et al., 1982). In addition, a correlation between this particle type and super-micron particles measured by the APS has been found, suggesting that largersized bioparticles were also present. In addition, the AA particle type $(\mathrm{N}: \mathrm{C}$ ratio $=0.13)$ and its atmospheric transport are also relevant with respect to the local nitrogen balance, especially since particulate matter is known to exhibit smaller deposition rates than reactive gas-phase compounds (Nemitz et al., 2009). Nitrogen-containing aerosol can be an important factor in the marine nitrogen cycle (Wedyan and Preston, 2008; Cape et al., 2011).

The other parts of the organic aerosol fraction consisted of marine oxygenated organic aerosol (M-OOA, 41\%), methanesulfonic acid fragments $(25 \%)$, sea spray organic fragments $(7 \%)$ and locally produced hydrocarbon-like OA (9\%). A special treatment of the sea salt contribution through the identification of additional inorganic peaks in the AMS unit mass resolution and high-resolution fragmentation tables was developed and applied to the sea spray OA PMF factor. The M-OOA aerosol type exhibited a strong correlation with aged marine aerosol observed at Mace Head, Ireland (Ovadnevaite et al., 2011).

The unique dataset from Bird Island described here confirmed high organic contributions to remote marine aerosol found in other recent studies through MSA-OA originating from phytoplankton decay processes. In addition, the data revealed new aspects, including the significant biogenic influence of seabirds and seals on the chemical composition of local aerosol, both via ammonia neutralisation and amino acid emission. The observation of biological particles is especially interesting with respect to their potential ice nucleating abilities (Pöschl et al., 2010). Further investigations including the exact determination of the source and the occurrence at locations (e.g. near northern hemispheric seabird colonies) and model simulations for the export of these particles out of the boundary layer could reveal whether marine fauna is a source for ice nuclei in the marine aerosol, and whether this could have an impact on cloud properties, in- fluencing precipitation patterns and the radiative balance at larger geographical scales.

\section{Supplementary material related to this article is available online at http://www.atmos-chem-phys.net/13/ 8669/2013/acp-13-8669-2013-supplement.pdf.}

Acknowledgements. This work was supported through the NERC AFI-CGS-069 project, the CEH Environmental Change Integrating Fund, and the Max Planck Institute for Chemistry.

The authors thank the fabulous British Antarctic Survey and Bird Island crews as well as the three reviewers for their constructive comments.

The service charges for this open access publication have been covered by the Max Planck Society.

Edited by: A. Petzold

\section{References}

Allan, J. D., Bower, K. N., Coe, H., Boudries, H., Jayne, J. T., Canagaratna, M. R., Millet, D. B., Goldstein, A. H., Quinn, P. K., Weber, R. J., and Worsnop, D. R.: Submicron aerosol composition at Trinidad Head, California, during ITCT 2K2: Its relationship with gas phase volatile organic carbon and assessment of instrument performance, J. Geophys. Res., 109, D23s24, doi:10.1029/2003jd004208, 2004a.

Allan, J. D., Delia, A. E., Coe, H., Bower, K. N., Alfarra, M. R., Jimenez, J. L., Middlebrook, A. M., Drewnick, F., Onasch, T. B., Canagaratna, M. R., Jayne, J. T., and Worsnopf, D. R.: A generalised method for the extraction of chemically resolved mass spectra from aerodyne aerosol mass spectrometer data, J. Aerosol. Sci., 35, 909-922, doi:10.1016/j.jaerosci.2004.02.007, 2004 b.

Aller, J. Y., Kuznetsova, M. R., Jahns, C. J., and Kemp, P. F.: The sea surface microlayer as a source of viral and bacterial enrichment in marine aerosols, J. Aerosol. Sci., 36, 801-812, doi:10.1016/j.jaerosci.2004.10.012, 2005.

Bahreini, R., Jimenez, J. L., Wang, J., Flagan, R. C., Seinfeld, J. H., Jayne, J. T., and Worsnop, D. R.: Aircraft-based aerosol size and composition measurements during ACE-Asia using an Aerodyne aerosol mass spectrometer, J. Geophys. Res., 108, 22, 8645, doi:10.1029/2002jd003226, 2003.

Bates, T. S., Calhoun, J. A., and Quinn, P. K.: Variations in the concentration ratio of methane-sulfonate to sulfate in marine aerosol particles over the South Pacific Ocean, J. Geophys. Res., 97, 9859-9865, 1992.

Bates, T. S., Huebert, B. J., Gras, J. L., Griffiths, F. B., and Durkee, P. A.: International Global Atmospheric Chemistry (IGAC) Project's First Aerosol Characterization Experiment (ACE 1): Overview. J. Geophys. Res. Solid Earth, 103, 16297-16318, 1998. 
Beyer, L., Knicker, H., Blume, H. P., Bolter, M., Vogt, B., and Schneider, D.: Soil organic matter of suggested spodic horizons in relic ornithogenic soils of coastal continental Antarctica (Casey Station, Wilkes Land) in comparison with that of spodic soil horizons in Germany, Soil Sci., 162, 518-527, doi:10.1097/00010694-199707000-00007, 1997.

Blackall, T. D., Wilson, L. J., Theobald, M. R., Milford, C., Nemitz, E., Bull, J., Bacon, P. J., Hamer, K. C., Wanless, S., and Sutton, M. A.: Ammonia emissions from seabird colonies, Geophys. Res. Let. , 34, L10801, doi:10.1029/2006gl028928, 2007.

Blanchard, D. C. and Woodcock, A. H.: Bubble formation and modification in the sea and its meteorological significance, Tellus, 9, 145-158, 1957

Burrows, S. M., Hoose, C., Pöschl, U., and Lawrence, M. G.: Ice nuclei in marine air: biogenic particles or dust?, Atmos. Chem. Phys., 13, 245-267, doi:10.5194/acp-13-245-2013, 2013.

Canagaratna, M. R., Jayne, J. T., Jimenez, J. L., Allan, J. D., Alfarra, M. R., Zhang, Q., Onasch, T. B., Drewnick, F., Coe, H., Middlebrook, A., Delia, A., Williams, L. R., Trimborn, A. M., Northway, M. J., DeCarlo, P. F., Kolb, C. E., Davidovits, P., and Worsnop, D. R.: Chemical and microphysical characterization of ambient aerosols with the aerodyne aerosol mass spectrometer, Mass Spectrom. Rev., 26, 185-222, doi:10.1002/mas.20115, 2007

Cape, J. N., Cornell, S. E., Jickells, T. D., and Nemitz, E.: Organic nitrogen in the atmosphere - Where does it come from? A review of sources and methods, Atmos. Res., 102, 30-48, doi:10.1016/j.atmosres.2011.07.009, 2011.

Cavalli, F., Facchini, M. C., Decesari, S., Mircea, M., Emblico, L., Fuzzi, S., Ceburnis, D., Yoon, Y. J., O’Dowd, C. D., Putaud, J. P., and Dell'Acqua, A.: Advances in characterization of size-resolved organic matter in marine aerosol over the North Atlantic, J. Geophys. Res., 109, D24215, doi:10.1029/2004jd005137, 2004.

Chang, R. Y.-W., Leck, C., Graus, M., Müller, M., Paatero, J., Burkhart, J. F., Stohl, A., Orr, L. H., Hayden, K., Li, S.-M., Hansel, A., Tjernström, M., Leaitch, W. R., and Abbatt, J. P. D.: Aerosol composition and sources in the central Arctic Ocean during ASCOS, Atmos. Chem. Phys., 11, 10619-10636, doi:10.5194/acp-11-10619-2011, 2011.

Ceburnis, D., Garbaras, A., Szidat, S., Rinaldi, M., Fahrni, S., Perron, N., Wacker, L., Leinert, S., Remeikis, V., Facchini, M. C., Prevot, A. S. H., Jennings, S. G., Ramonet, M., and O'Dowd, C. D.: Quantification of the carbonaceous matter origin in submicron marine aerosol by ${ }^{13} \mathrm{C}$ and ${ }^{14} \mathrm{C}$ isotope analysis, Atmos. Chem. Phys., 11, 8593-8606, doi:10.5194/acp-11-85932011, 2011.

Claeys, M., Wang, W., Vermeylen, R., Kourtchev, I., Chi, X., Farhat, Y., Surratt, J. D., Gómez-González, Y., Sciare, J., and Maenhaut, W.: Chemical characterisation of marine aerosol at Amsterdam Island during the austral summer of 2006-2007, J. Aerosol. Sci., 41, 13-22, doi:10.1016/j.jaerosci.2009.08.003, 2010.

Crippa, M., El Haddad, I., Slowik, J. G., DeCarlo, P., Mohr, C., Heringa, M. F., Chirico, R., Marchand, N., Sciare, J., Baltensperger, U., and Prevot, A. S. H.: Identification of marine and continental aerosol sources in Paris using high resolution aerosol mass spectrometry, J. Geophys. Res., 118, 1-19, doi:10.1002/jgrd.50151, 2013.
Crosier, J., Allan, J. D., Coe, H., Bower, K. N., Formenti, P., and Williams, P. I.: Chemical composition of summertime aerosol in the Po Valley (Italy), northern Adriatic and Black Sea, Q. J. Roy. Meteorol. Soc., 133, 61-75, doi:10.1002/qj.88, 2007.

Dall'Osto, M., Ceburnis, D., Monahan, C., Worsnop, D. R., Bialek, J., Kulmala, M., Kurten, T., Ehn, M., Wenger, J. C., Sodeau, J., Healy, R., and O'Dowd, C.: Nitrogenated and aliphatic organic vapors as possible drivers for marine secondary organic aerosol growth, J. Geophys. Res., 117, D12311, doi:10.1029/2012JD017522, 2012.

DeCarlo, P. F., Slowik, J. G., Worsnop, D. R., Davidovits, P., and Jimenez, J. L.: Particle morphology and density characterization by combined mobility and aerodynamic diameter measurements. Part 1: Theory, Aerosol Sci. Technol., 38, 1185-1205, doi:10.1080/027868290903907, 2004.

DeCarlo, P. F., Kimmel, J. R., Trimborn, A., Northway, M. J., Jayne, J. T., Aiken, A. C., Gonin, M., Fuhrer, K., Horvath, T., Docherty, K. S., Worsnop, D. R., and Jimenez, J. L.: Field-deployable, high-resolution, time-of-flight aerosol mass spectrometer, Anal. Chem., 78, 8281-8289, doi:10.1021/ac061249n, 2006.

Decesari, S., Finessi, E., Rinaldi, M., Paglione, M., Fuzzi, S., Stephanou, E. G., Tziaras, T., Spyros, A., Ceburnis, D., O’Dowd, C., Dall'Osto, M., Harrison, R. M., Allan, J., Coe, H., and Facchini, M. C.: Primary and secondary marine organic aerosols over the North Atlantic Ocean during the MAP experiment, J. Geophys. Res., 116, D22210, doi:10.1029/2011jd016204, 2011.

De Laeter, J. R., Böhlke, J. K., De Bièvre, P., Hidaka, H., Peiser, H. S., Rosman, K. J. R., and Taylor, P. D. P.: Atomic weights of the elements: Review 2000 (IUPAC Technical Report), Pure Appl. Chem., 75, 683-800, 2003.

Draxler, R. R. and Rolph, G. D.: HYSPLIT (HYbrid Single-Particle Lagrangian Integrated Trajectory) Model access via NOAA ARL READY Website (http://ready.arl.noaa.gov/HYSPLIT. php), NOAA Air Resources Laboratory, Silver Spring, MD, 2011.

Drewnick, F., Hings, S. S., DeCarlo, P., Jayne, J. T., Gonin, M. Fuhrer, K., Weimer, S., Jimenez, J. L., Demerjian, K. L., Borrmann, S., and Worsnop, D. R.: A new time-of-flight aerosol mass spectrometer (TOF-AMS) - Instrument description and first field deployment, Aerosol Sci. Technol., 39, 637-658, doi:10.1080/02786820500182040, 2005.

Facchini, M. C., Decesari, S., Rinaldi, M., Carbone, C., Finessi, E., Mircea, M., Fuzzi, S., Moretti, F., Tagliavini, E., Ceburnis, D., and O'Dowd, C. D.: Important Source of Marine Secondary Organic Aerosol from Biogenic Amines, Environ. Sci. Technol., 42, 9116-9121, doi:10.1021/es8018385, 2008a.

Facchini, M. C., Rinaldi, M., Decesari, S., Carbone, C., Finessi, E., Mircea, M., Fuzzi, S., Ceburnis, D., Flanagan, R., Nilsson, E. D., de Leeuw, G., Martino, M., Woeltjen, J., and O'Dowd, C. D.: Primary submicron marine aerosol dominated by insoluble organic colloids and aggregates, Geophys. Res. Lett., 35, L17814, doi:10.1029/2008g1034210, 2008b.

Freutel, F., Schneider, J., Drewnick, F., von der Weiden-Reinmüller, S.-L., Crippa, M., Prévôt, A. S. H., Baltensperger, U., Poulain, L., Wiedensohler, A., Sciare, J., Sarda-Estève, R., Burkhart, J. F., Eckhardt, S., Stohl, A., Gros, V., Colomb, A., Michoud, V., Doussin, J. F., Borbon, A., Haeffelin, M., Morille, Y., Beekmann, M., and Borrmann, S.: Aerosol particle measurements at three stationary sites in the megacity of Paris during summer 2009: 
meteorology and air mass origin dominate aerosol particle composition and size distribution, Atmos. Chem. Phys., 13, 933-959, doi:10.5194/acp-13-933-2013, 2013.

Gantt, B. and Meskhidze, N.: The physical and chemical characteristics of marine primary organic aerosol: a review, Atmos. Chem. Phys., 13, 3979-3996, doi:10.5194/acp-13-3979-2013, 2013.

Gantt, B., Meskhidze, N., Facchini, M. C., Rinaldi, M., Ceburnis, D., and O'Dowd, C. D.: Wind speed dependent size-resolved parameterization for the organic mass fraction of sea spray aerosol, Atmos. Chem. Phys., 11, 8777-8790, doi:10.5194/acp-11-87772011, 2011.

Gaston, C. J., Furutani, H., Guazzotti, S. A., Coffee, K. R., Bates, T. S., Quinn, P. K., Aluwihare, L. I., Mitchell, B. G., and Prather, K. A.: Unique ocean-derived particles serve as a proxy for changes in ocean chemistry, J. Geophys. Res., 116, D18310, doi:10.1029/2010jd015289, 2011.

Ge, X., Wexler, A. S., and Clegg, S. L.: Atmospheric amines e Part I. A review, Atmos. Environ., 45, 524-546, doi:10.1016/j.atmosenv.2010.10.012, 2011.

Hawkins, L. N. and Russell, L. M.: and Polysaccharides, Proteins, and Phytoplankton Fragments: Four Chemically Distinct Types of Marine Primary Organic Aerosol Classified by Single Particle Spectromicroscopy, Adv. Meteorol., 2010, 612132, doi:10.1155/2010/612132, 2010.

Hildebrandt, L., Kostenidou, E., Lanz, V. A., Prevot, A. S. H., Baltensperger, U., Mihalopoulos, N., Laaksonen, A., Donahue, N. M., and Pandis, S. N.: Sources and atmospheric processing of organic aerosol in the Mediterranean: insights from aerosol mass spectrometer factor analysis, Atmos. Chem. Phys., 11, 1249912515, doi:10.5194/acp-11-12499-2011, 2011.

Hings, S. S., Walter, S., Schneider, J., Borrmann, S., and Drewnick, F.: Comparison of a quadrupole and a time-of-flight aerosol mass spectrometer during the Feldberg aerosol characterization experiment 2004, Aerosol Sci. Technol., 41, 679-691, doi:10.1080/02786820701408483, 2007.

Huffman, J. A., Jayne, J. T., Drewnick, F., Aiken, A. C., Onasch, T., Worsnop, D. R., and Jimenez, J. L.: Design, modeling, optimization, and experimental tests of a particle beam width probe for the aerodyne aerosol mass spectrometer, Aerosol Sci. Technol., 39, 1143-1163, doi:10.1080/02786820500423782, 2005.

Huffman, J. A., Treutlein, B., and Pöschl, U.: Fluorescent biological aerosol particle concentrations and size distributions measured with an Ultraviolet Aerodynamic Particle Sizer (UVAPS) in Central Europe, Atmos. Chem. Phys., 10, 3215-3233, doi:10.5194/acp-10-3215-2010, 2010.

Jimenez, J. L., Jayne, J. T., Quan, S., Kolb, C. E., Worsnop, D. R., Yourshaw, I., Seinfeld, J. H., Flagan, R. C., Xuefeng, Z., Smith, K. A., Morris, J. W., and Davidovits, P.: Ambient aerosol sampling using the aerodyne aerosol mass spectrometer, J. Geophys. Res., 108, SOS13-11-SOS13-SOS13-13, doi:10.1029/2001jd001213, 2003.

Johnson, M. T. and Bell, T. G.: Coupling between dimethylsulfide emissions and the ocean-atmosphere exchange of ammonia, Environ. Chem., 5, 259-267, doi:10.1071/en08030, 2008.

Johnson, M. T., Liss, P. S., Bell, T. G., Lesworth, T. J., Baker, A. R., Hind, A. J., Jickells, T. D., Biswas, K. F., Woodward, E. M. S., and Gibb, S. W.: Field observations of the ocean atmosphere exchange of ammonia: Fundamental importance of temperature as revealed by a comparison of high and low latitudes, Global
Biogeochem. Cy., 22, 1019-1034, 2008.

Jourdain, B. and Legrand, M.: Seasonal variations of dimethyl sulfide, dimethyl sulfoxide, sulfur dioxyde, methanesulfonate, and non-sea-salt sulfate aerosols at Dumont d'Urville (December 1998-July 1999), J. Geophys. Res., 106, 14391-14408, 2001.

Korb, R. E. and Whitehouse, M.: SeaWiFS in the southern ocean: spatial and temporal variability in phytoplankton biomass around South Georgia, Deep-Sea Res. I, 51, 721-738, doi:10.1016/j.dsr.2004.02.006, 2004.

Korb, R. E., Whitehouse, M., and Ward, P.: SeaWiFS in the southern ocean: spatial and temporal variability in phytoplankton biomass around South Georgia, Deep-Sea Res. II, 51, 99-116, doi:10.1016/j.dsr2.2003.04.002, 2004.

Korb, R. E., Whitehouse, M., Atkinson, A., and Thorpe, S. E.: Magnitude and maintenance of the phytoplankton bloom at South Georgia: a naturally iron-replete environment, Mar. Ecol.-Prog. Ser., 368, 75-91, doi:10.3354/meps07525, 2008.

Kuznetsova, M., Lee, C., and Aller, J.: Characterization of the proteinaceous matter in marine aerosols, Mar. Chem., 96, 359-377, doi:10.1016/j.marchem.2005.03.007, 2005.

Lanz, V. A., Alfarra, M. R., Baltensperger, U., Buchmann, B., Hueglin, C., and Prévôt, A. S. H.: Source apportionment of submicron organic aerosols at an urban site by factor analytical modelling of aerosol mass spectra, Atmos. Chem. Phys., 7, 15031522, doi:10.5194/acp-7-1503-2007, 2007.

Lapina, K., Heald, C. L., Spracklen, D. V., Arnold, S. R., Allan, J. D., Coe, H., McFiggans, G., Zorn, S. R., Drewnick, F., Bates, T. S., Hawkins, L. N., Russell, L. M., Smirnov, A., O’Dowd, C. D., and Hind, A. J.: Investigating organic aerosol loading in the remote marine environment, Atmos. Chem. Phys., 11, 8847-8860, doi:10.5194/acp-11-8847-2011, 2011.

Legrand, M. R., Lorius, C., Barkov, N. I., and Petrov, V. N.: Vostok (Antarctica) ice core: Atmospheric chemistry changes over the last climatic cycle (160,000 years), Atmos. Environ., 22, 317 331, 1988.

Legrand, M., Ducroz, F., Wagenbach, D., Mulvaney, R., and Hall, J.: Ammonium in coastal Antarctic aerosol and snow: Role of polar ocean and penguin emissions, J. Geophys. Res., 103, $11043-$ 11056, 1998.

Legrand, M., Gros, V., Preunkert, S., Sarda-Esteve, R., Thierry, A. M., Pepy, G., and Jourdain, B.: A reassessment of the budget of formic and acetic acids in the boundary layer at Dumont d'Urville (coastal Antarctica): The role of penguin emissions on the budget of several oxygenated volatile organic compounds, J. Geophys. Res., 117, D06308, doi:10.1029/2011jd017102, 2012.

Matthew, B. M., Middlebrook, A. M., and Onasch, T. B.: Collection efficiencies in an Aerodyne Aerosol Mass Spectrometer as a function of particle phase for laboratory generated aerosols, Aerosol Sci. Technol., 42, 884-898, doi:10.1080/02786820802356797, 2008.

Meskhidze, N., Xu, J., Gantt, B., Zhang, Y., Nenes, A., Ghan, S. J., Liu, X., Easter, R., and Zaveri, R.: Global distribution and climate forcing of marine organic aerosol: 1. Model improvements and evaluation, Atmos. Chem. Phys., 11, 11689-11705, doi:10.5194/acp-11-11689-2011, 2011.

Müller, C., Iinuma, Y., Karstensen, J., van Pinxteren, D., Lehmann, S., Gnauk, T., and Herrmann, H.: Seasonal variation of aliphatic amines in marine sub-micrometer particles at the Cape Verde islands, Atmos. Chem. Phys., 9, 9587-9597, doi:10.5194/acp-9- 
9587-2009, 2009.

Murphy, M. E., King, J. R., Taruscio, T. G., and Geupel, G. R.: Amino Acid Composition of Feather Barbs and Rachises in Three Species of Pygoscelid Penguins: Nutritional Implications, The Condor, 92, 913-921, 1990.

Nemitz, E., Dorsey, J. R., Flynn, M. J., Gallagher, M. W., Hensen, A., Erisman, J.-W., Owen, S. M., Dämmgen, U., and Sutton, M. A.: Aerosol fluxes and particle growth above managed grassland, Biogeosciences, 6, 1627-1645, doi:10.5194/bg-6-16272009, 2009.

Ng, N. L., Canagaratna, M. R., Zhang, Q., Jimenez, J. L., Tian, J., Ulbrich, I. M., Kroll, J. H., Docherty, K. S., Chhabra, P. S., Bahreini, R., Murphy, S. M., Seinfeld, J. H., Hildebrandt, L., Donahue, N. M., DeCarlo, P. F., Lanz, V. A., Prévôt, A. S. H., Dinar, E., Rudich, Y., and Worsnop, D. R.: Organic aerosol components observed in Northern Hemispheric datasets from Aerosol Mass Spectrometry, Atmos. Chem. Phys., 10, 46254641, doi:10.5194/acp-10-4625-2010, 2010.

Ng, N. L., Canagaratna, M. R., Jimenez, J. L., Zhang, Q., Ulbrich, I. M., and Worsnop, D. R.: Real-Time Methods for Estimating Organic Component Mass Concentrations from Aerosol Mass Spectrometer Data, Environ. Sci. Technol., 45, 910-916, doi:10.1021/es102951k, 2011.

Norman, M., Spirig, C., Wolff, V., Trebs, I., Flechard, C., Wisthaler, A., Schnitzhofer, R., Hansel, A., and Neftel, A.: Intercomparison of ammonia measurement techniques at an intensively managed grassland site (Oensingen, Switzerland), Atmos. Chem. Phys., 9, 2635-2645, doi:10.5194/acp-9-2635-2009, 2009.

O'Dowd, C. and de Leeuw, G.: Marine aerosol production: a review of current knowledge, Phil. Trans. R. Soc. A, 365, 1753-1774, 2007.

O’Dowd, C. D., Facchini, M. C., Cavalli, F., Ceburnis, D., Mircea, M., Decesari, S., Fuzzi, S., Yoon, Y. J., and Putaud, J. P.: Biogenically driven organic contribution to marine aerosol, Nature, 431, 676-680, doi:10.1038/nature02959, 2004.

O’Dowd, C. D., Langmann, B., Varghese, S., Scannell, C., Ceburnis, D., and Facchini, M. C.: A combined organic-inorganic sea-spray source function, Geophys. Res. Lett., 35, L01801, doi:10.1029/2007g1030331, 2008.

Ovadnevaite, J., O’Dowd, C., Dall'Osto, M., Ceburnis, D., Worsnop, D. R., and Berresheim, H.: Detecting high contributions of primary organic matter to marine aerosol: A case study, Geophys. Res. Lett., 38, L02807, doi:10.1029/2010gl046083, 2011.

Ovadnevaite, J., Ceburnis, D., Canagaratna, M., Berresheim, H., Bialek, J., Martucci, G., Worsnop, D. R., and O'Dowd, C.: On the effect of wind speed on submicron sea salt mass concentratio and source fluxes, J. Geophys. Res., 117, D16201, doi:10.1029/2011JD017379, 2012.

Paatero, P. and Tapper, U.: Positive matrix factorizaion A nonnegative factor model iwth optimal utilization of error-estimates of data values, Environmetrics, 5, 111-126, doi:10.1002/env.3170050203, 1994.

Peters, T. M. and Leith, D.: Concentration measurement and counting efficiency of the aerodynamic particle sizer 3321, J. Aerosol. Sci., 34, 627-634, doi:10.1016/S0021-8502/0300030-2, 2003.

Phinney, L., Leaitch, W. R., Lohmann, U., Boudries, H., Worsnop, D. R., Jayne, J. T., Toom-Sauntry, D., Wadleigh, M., Sharma, S., and Shantz, N.: Characterization of the aerosol over the sub- arctic north east Pacific Ocean, Deep-Sea Res. II, 53, 2410-2433, doi:10.1016/j.dsr2.2006.05.044, 2006.

Pöschl, U., Martin, S. T., Sinha, B., Chen, Q., Gunthe, S. S., Huffman, J. A., Borrmann, S., Farmer, D. K., Garland, R. M., Helas, G., Jimenez, J. L., King, S. M., Manzi, A., Mikhailov, E., Pauliquevis, T., Petters, M. D., Prenni, A. J., Roldin, P., Rose, D., Schneider, J., Su, H., Zorn, S. R., Artaxo, P., and Andreae, M. O.: Rainforest Aerosols as Biogenic Nuclei of Clouds and Precipitation in the Amazon, Science, 329, 15131516, doi:10.1126/science.1191056, 2010.

Pósfai, M., Li, J., Anderson, J. R., and Buseck, P. R.: Aerosol bacteria over the Southern Ocean during ACE-1, Atmos. Res., 66, 231-240, 2003.

Quinn, P. K., Coffman, D. J., Kapustin, V. N., Bates, T. S., and Covert, D. S.: Aerosol optical properties in the marine boundary layer during the First Aerosol Characterization Experiment (ACE 1) and the underlying chemical and physical aerosol properties, J. Geophys. Res., 103, 16547-16563, doi:10.1029/97jd02345, 1998.

Quinn, P. K., Bates, T. S., Coffman, D., Onasch, T. B., Worsnop, D., Baynard, T., de Gouw, J. A., Goldan, P. D., Kuster, W. C., Williams, E., Roberts, J. M., Lerner, B., Stohl, A., Pettersson, A., and Lovejoy, E. R.: Impacts of sources and aging on submicrometer aerosol properties in the marine boundary layer across the Gulf of Maine, J. Geophys. Res., 111, D23s36, doi:10.1029/2006jd007582, 2006.

Riddick, S. N., Dragosits, U., Blackall, T. D., Daunt, F., Wanless, S., and Sutton, M. A.: The global distribution of ammonia emissions from seabird colonies, Atmos. Environ., 55, 319-327, doi:10.1016/j.atmosenv.2012.02.052, 2012.

Rinaldi, M., Decesari, S., Finessi, E., Giulianelli, L., Carbone, C., Fuzzi, S., O’Dowd, C., Ceburnis, D., and Facchini, M. C.: Primary and Secondary Organic Marine Aerosol and Oceanic Biological Activity: Recent Results and New Perspectives for Future Studies, Adv. Meteorol., 2010, 310682, doi:10.1155/2010/310682, 2010.

Russell, L. M., Hawkins, L. N., Frossard, A. A., Quinn, P. K., and Bates, T. S.: Carbohydrate-like composition of submicron atmospheric particles and their production from ocean bubble bursting, P. Natl. Acad. Sci. USA, 107, 6652-6657, doi:10.1073/pnas.0908905107, 2010.

Saltzman, E., Savoie, D. L., Zika, R. G., and Prospero, J. M.: Methane sulfonic acid in the marine atmosphere, J. Geophys. Res., 4, 227-240, 1983.

Scalabrin, E., Zangrando, R., Barbaro, E., Kehrwald, N. M., Gabrieli, J., Barbante, C., and Gambaro, A.: Amino acids in Arctic aerosols, Atmos. Chem. Phys., 12, 10453-10463, doi:10.5194/acp-12-10453-2012, 2012.

Schmale, J., Schneider, J., Jurkat, T., Voigt, C., Kalesse, H., Rautenhaus, M., Lichtenstern, M., Schlager, H., Ancellet, G., Arnold, F., Gerding, M., Mattis, I., Wendisch, M., and Borrmann, S.: Aerosol layers from the 2008 eruptions of Mount Okmok and Mount Kasatochi: In situ upper troposphere and lower stratosphere measurements of sulfate and organics over Europe, J. Geophys. Res., 115, D00L07, doi:10.1029/2009JD013628, 2010.

Schneider, J., Freutel, F., Zorn, S. R., Chen, Q., Farmer, D. K., Jimenez, J. L., Martin, S. T., Artaxo, P., Wiedensohler, A., and Borrmann, S.: Mass-spectrometric identification of primary bi- 
ological particle markers and application to pristine submicron aerosol measurements in Amazonia, Atmos. Chem. Phys., 11, 11415-11429, doi:10.5194/acp-11-11415-2011, 2011.

Sciare, J., Favez, O., Sarda-Esteve, R., Oikonomou, K., Cachier, H., and Kazan, V.: Long-term observations of carbonaceous aerosols in the Austral Ocean atmosphere: Evidence of a biogenic marine organic source, J. Geophys. Res., 114, D15302, doi:10.1029/2009jd011998, 2009.

Seinfeld, J. and Pandis, S. N.: Atmos. Chem. Phys.: From air pollution to climate change, 2nd ed., Wiley-Interscience, 2006.

Shank, L. M., Howell, S., Clarke, A. D., Freitag, S., Brekhovskikh, V., Kapustin, V., McNaughton, C., Campos, T., and Wood, R.: Organic matter and non-refractory aerosol over the remote Southeast Pacific: oceanic and combustion sources, Atmos. Chem. Phys., 12, 557-576, doi:10.5194/acp-12-557-2012, 2012.

Sueper, D.: ToF high resolution AMS analysis guide available at: 2 June 2012.

Sun, Y. L., Zhang, Q., Schwab, J. J., Yang, T., Ng, N. L., and Demerjian, K. L.: Factor analysis of combined organic and inorganic aerosol mass spectra from high resolution aerosol mass spectrometer measurements, Atmos. Chem. Phys., 12, 8537-8551, doi:10.5194/acp-12-8537-2012, 2012.

Ulbrich, I. M., Canagaratna, M. R., Zhang, Q., Worsnop, D. R., and Jimenez, J. L.: Interpretation of organic components from Positive Matrix Factorization of aerosol mass spectrometric data, Atmos. Chem. Phys., 9, 2891-2918, doi:10.5194/acp-9-2891-2009, 2009.

Vignati, E., Facchini, M. C., Rinaldi, M., Scannell, C., Ceburnis, D., Sciare, J., Kanakidou, M., Myriokefalitakis, S., Dentener, F., and O'Dowd, C.: Global scale emissions and distribution of seaspray aerosol: sea-salt and organic enrichment, Atmos. Environ., 44, 670-677, 2010.

von der Weiden, S.-L., Drewnick, F., and Borrmann, S.: Particle Loss Calculator - a new software tool for the assessment of the performance of aerosol inlet systems, Atmos. Meas. Tech., 2, 479-494, doi:10.5194/amt-2-479-2009, 2009.

Watson, J. D., Baker, T. A., Bell, S. P., Gann, A. A. F., Levine, M., and Losick, R. M.: Molecular biology of the gene, 6th ed., New Jersey, Benjamin Cummings, 2007.
Wedral, E. M., Vadehra, D. V., and Baker, R. C.: Chemical composition of cuticle, and inner and outer shell membranes from eggs of gallus-gallus, Comparative Biochemistry and Physiology, 47, 631-640, doi:10.1016/0305-0491(74)90011-x, 1974.

Wedyan, M. A. and Preston, M. R.: The coupling of surface seawater organic nitrogen and the marine aerosol as inferred from enantiomer-specific amino acid analysis, Atmos. Environ., 42, 8698-8705, 2008.

Williams, A. J., Siegfried, W. R., and Cooper, J.: Egg composition and hatchling precocity in seabirds, Ibis, 124, 456-470, doi:10.1111/j.1474-919X.1982.tb03791.x, 1982.

Zhang, Q., Alfarra, M. R., Worsnop, D. R., Allan, J. D., Coe, H., Canagaratna, M. R., and Jimenez, J. L.: Deconvolution and quantification of hydrocarbon-like and oxygenated organic aerosols based on aerosol mass spectrometry, Environ. Sci. Technol., 39, 4938-4952, doi:10.1021/es0485681, 2005.

Zhang, Q., Jimenez, J. L., Canagaratna, M. R., Ulbrich, I. M., Ng, N. L., Worsnop, D. R., and Sun, Y. L.: Understanding atmospheric organic aerosols via factor analysis of aerosol mass spectrometry: a review, Anal. Bioanal. Chem., 401, 3045-3067, doi:10.1007/s00216-011-5355-y, 2011.

Zhu, R. B., Sun, J. J., Liu, Y. S., Gong, Z. J., and Sun, L. G.: Potential ammonia emissions from penguin guano, ornithogenic soils and seal colony soils in coastal Antarctica: effects of freezingthawing cycles and selected environmental variables, Antarct. Sci., 23, 78-92, doi:10.1017/s0954102010000623, 2011.

Zorn, S. R.: Chemical Composition Measurements of Pristine Aerosols in the Southern Atlantic and Amazonian Regions by Means of On-line Time-of-Flight Aerosol Mass Spectrometry, $\mathrm{PhD}$, Fachbereich Physik, Mathematik und Informatik, Johannes Gutenberg-University Mainz, Mainz, Germany, 2009.

Zorn, S. R., Drewnick, F., Schott, M., Hoffmann, T., and Borrmann, S.: Characterization of the South Atlantic marine boundary layer aerosol using an aerodyne aerosol mass spectrometer, Atmos. Chem. Phys., 8, 4711-4728, doi:10.5194/acp-8-47112008, 2008. 